\title{
Dietary lipids and forages interactions on cow and goat milk fatty acid composition and sensory properties
}

\author{
Yves ChILliarD*, Anne Ferlay \\ INRA Unité de Recherches sur les Herbivores, Équipe Tissu Adipeux et Lipides du Lait, \\ Theix, 63122 St-Genès-Champanelle, France
}

\begin{abstract}
This review summarises the known effects of dietary factors on bovine and caprine milk fatty acid composition, as well as the regulation of cow and goat mammary lipid secretion. Special attention is given to fatty acids that could play a role for human health, such as saturated fatty acids, oleic acid, n-6- or n-3-C18 to C22 polyunsaturated fatty acids, trans isomers of $\mathrm{C} 18: 1$ and $\mathrm{C} 18: 2$, and isomers of conjugated linoleic acid (CLA). The main dietary factors taken into account are the nature of forages, including pasture, the forage:concentrate ratio and diet starch content, and the supplementation of dairy rations with crude or processed vegetable oils or oilseeds, and vitamin $\mathrm{E}$. A particular emphasis is given to studies on interactions between these dietary factors, which show that there is a considerable plasticity of ruminant milk fatty acid composition. Despite the existence of several studies on the effects of dietary factors on the sensorial quality of milk and dairy products, there is a need to evaluate more deeply how the different feeding strategies could change the nutritional, sensorial and technological aspects of milk fat quality.
\end{abstract}

dairy cow / dairy goat / forages / oilseeds / milk / fatty acids / human health

\section{INTRODUCTION}

Dairy products provide 25 to $35 \%$ of the overall saturated fat consumed by man, which makes them the preferential target of dieticians' criticisms [1]. The deleterious reputation of saturated fatty acids (FA) should however be weighted with the fact that stearic acid has no atherogenic effect. The allegedly atherogenic effect of certain trans mono-unsaturated fatty acids has not been confirmed as regards the main isomer present in milk, i.e. vaccenic (trans11-18:1). The interest of increasing the $n-3 / n-6$ ratio of polyunsaturated fatty acids (PUFA) has been confirmed. Lastly, the properties of conjugated linoleic acid (CLA), whose main iso- mer, rumenic acid (cis9, trans 11-18:2), exhibits interesting features, as demonstrated in animal models, are now better known, for the prevention of certain forms of cancer in particular.

These new facts underline the interest of modulating the milk FA composition. Mammals' milk FA composition is linked to intrinsic (animal breed, genotype, lactation and pregnancy stages) or extrinsic (environmental) factors. In a given animal species, the effects linked to breed or genotype are significant but restricted [2-6] and they can only be achieved in the mid-term or through interaction with constraints inherent in other criteria. The lactation stage effect is marked and mainly linked to lipid

\footnotetext{
* Corresponding author: yves.chilliard@clermont.inra.fr
} 
Table I. Effects of dietary lipid supplementation on cow's milk yield and composition.

\begin{tabular}{|c|c|c|c|c|c|}
\hline Dietary lipids & $\mathrm{N}(\mathrm{A})^{1}$ & $\begin{array}{l}\text { Milk yield } \\
\left(\mathrm{kg} \cdot \mathrm{d}^{-1}\right)^{2}\end{array}$ & $\begin{array}{l}\text { Protein content } \\
\left(\mathrm{g} \cdot \mathrm{kg}^{-1}\right)\end{array}$ & $\begin{array}{c}\text { Fat content } \\
\left(\mathrm{g} \cdot \mathrm{kg}^{-1}\right)\end{array}$ & $\begin{array}{c}\text { Fat yield } \\
\left(\mathrm{g} \cdot \mathrm{d}^{-1}\right)\end{array}$ \\
\hline Animal fat $(\mathrm{AF})^{3}$ & $22(688)$ & +0.5 & $-0.6^{*}$ & -1.4 & -18 \\
\hline Encapsulated $\mathrm{AF}^{3}$ & $26(941)$ & $+1.0^{*}$ & $-1.8^{*}$ & $+4.0^{*}$ & $+143 *$ \\
\hline Saturated $\mathrm{FA}^{3}$ & $10(644)$ & $+1.7^{*}$ & $-0.6^{*}$ & +0.5 & $+58^{*}$ \\
\hline Palm oil Ca-salts ${ }^{3}$ & $29(593)$ & $+0.9^{*}$ & $-1.2^{*}$ & +0.4 & $+47^{*}$ \\
\hline Rapeseed oil $(\mathrm{RO})^{4}$ & $5(742)$ & $-1.9^{*}$ & 0.0 & $-5.9 *$ & $-215^{*}$ \\
\hline RO Ca-salts ${ }^{4}$ & $11(562)$ & +0.5 & $-2.0^{*}$ & $-3.9^{*}$ & $-94 *$ \\
\hline Rapeseeds 4,5 & $11(927)$ & +0.8 & $-0.3^{*}$ & $-3.1 *$ & $-83^{*}$ \\
\hline Heated rapeseeds ${ }^{4}$ & $10(531)$ & +0.1 & -0.5 & $-1.1^{*}$ & +39 \\
\hline Sunflower oil ${ }^{4}$ & $5(459)$ & +1.0 & $-1.1^{*}$ & $-3.4 *$ & $-57 *$ \\
\hline Sunflower seeds ${ }^{4,5}$ & $8(503)$ & +0.7 & +0.4 & -1.2 & +9 \\
\hline Soybean oil ${ }^{4}$ & $34(529)$ & +0.3 & $-0.8^{*}$ & $-3.3^{*}$ & $-63^{*}$ \\
\hline Soybeans ${ }^{5}$ & $18(517)$ & -0.7 & $-0.8^{*}$ & $+1.3^{*}$ & -2 \\
\hline Extruded soybeans ${ }^{4}$ & $16(544)$ & $+2.7^{*}$ & $-1.1 *$ & $-1.9^{*}$ & +29 \\
\hline Heated soybeans ${ }^{4}$ & $14(692)$ & $+1.7 *$ & $-1.1 *$ & 0.0 & $+49^{*}$ \\
\hline Linseed oil ${ }^{4}$ & $10(475)$ & $+1.3^{*}$ & $-0.9 *$ & -1.8 & -7 \\
\hline Linseeds ${ }^{4,5}$ & $8(686)$ & -0.4 & -0.5 & +0.3 & +3 \\
\hline Encapsulated vegetable oils ${ }^{3}$ & $26(693)$ & 0.0 & -0.8 & $+6.4^{*}$ & $+120 *$ \\
\hline Marine oils ${ }^{3}$ & $27(305)$ & +0.2 & $-1.2^{*}$ & $-9.1 *$ & $-208 *$ \\
\hline
\end{tabular}

${ }^{1}$ Number of lipid-supplemented groups (amount of lipids, $g \cdot d^{-1}$ ).

2 Effects expressed as "treated group-control group", $* P<0.05$.

${ }^{3}$ From [20].

${ }^{4}$ Review by A. Ferlay and Y. Chilliard, unpublished.

${ }^{5}$ Whole, rolled or ground.

store mobilisation in early lactation [7], but it only lasts a few weeks each year. In contrast, seasonal effects are quantitatively very important. Although certain effects of temperature or photoperiod can be evidenced, it is the variations of ruminant nutrition which determine most of the seasonal variations of milk FA composition. The effects of cheesemaking technology on FA composition are minimal in relation to those of feeding [8].

Nutrition therefore constitutes a natural and economical way for farmers to sharply and rapidly modulate milk FA composition, in particular by adding lipid supplements to the diet. The consequences of these practices on dairy cows' milk fat and protein synthesis and contents are now well known: a tendency to increase milk production (with saturated lipids and soybean in particular), slight but almost systematic decrease in protein contents, limited variations of the fat content except with rapeseed oil and especially with fish oil, which induce sharp decreases, and encapsulated lipids that strongly increase it (Tab. I). In contrast, nearly all types of lipid supplements induce a sharp increase in goat milk fat content without modifying milk yield or protein content [7]. After a reminder of the mammary lipogenesis metabolic pathways, this article successively analyses the impacts of dairy cows' and goats' diets on the main fatty acid 
classes: saturated and cis mono-unsaturated, polyunsaturated and lastly CLA and trans mono-unsaturated. Then the effects of nutrition on the sensory characteristics of dairy products will be briefly evoked, as they may partly be due to post-milking lipolysis of milk fat (short-chain fatty acid release) or to polyunsaturated fatty acid oxidation.

\section{METABOLIC PATHWAYS NUTRIENT FLUXES INVOLVED IN MILK FAT SYNTHESIS}

\subsection{Mammary lipogenesis}

Milk fatty acids have a dual origin: they are either taken up from plasma lipoproteins $(60 \%$ of the fatty acids secreted in milk, [9]) or they are synthesized de novo in the mammary gland from acetate and 3-hydroxybutyrate. The main metabolic pathway involves two key enzymes: acetylCoA carboxylase (ACC) and fatty acid synthetase (FAS). FAS synthesizes FAs that feature up to 16 carbon atoms. The cellular and molecular factors that regulate the chain length of the fatty acids synthesized, within the same species or between the various ruminants species, have yet to be identified. As an example, the factors that determine the specificities of goat milk, which contains more 8 - and especially 10 -carbonatom fatty acids [10], are very little-known.

Pre-formed fatty acids are transported in plasma as non-esterified fatty acids (NEFA) or as triglyceride-rich lipoproteins. Lipoprotein lipase (LPL) permits triglyceride hydrolysis and FA uptake by the mammary gland. The amount of triglyceride uptake is generally well-correlated to its plasma concentration. Furthermore, the mammary gland uses plasma NEFA released by adipose tissue as a source of long-chain FA for milk lipid synthesis. The FAs stored as triglycerides in ruminant adipose tissue mainly are 16:0, 18:0 and cis9-18:1. For this reason, lipid mobilization, which occurs in early lactation and/or when the energy balance is negative, induces a sharp increase in stearic and oleic acids in milk [7].
The mammary gland cannot convert C16:0 into C18:0 by extending the carbon chain. Moreover, totally differentiated secretory mammary cells exhibit high delta- 9 desaturase activity, which converts stearic acid into oleic acid (cis9-18:1) and so contributes more than $50 \%$ of all the oleic acid secreted in milk $[11,12]$. In addition, approximately $30 \%$ of the vaccenic acid (trans 11 18:1) originated in the rumen can be desaturated to form rumenic acid (cis9, trans1118:2), the main isomer of CLA in milk [13]. Other minor conjugated or non conjugated isomers of C18:2 are probably synthesized by delta- 9 desaturation of other trans-18:1 isomers $[14,15]$.

These various metabolic pathways (de novo synthesis, uptake from plasma, desaturation) contribute to the formation of a pool of FAs that are used for triglyceride formation (97 to $98 \%$ of milk total lipids) through esterification on glycerol. FA asymmetrical distribution on the glycerol molecule influences the physical properties of milk fat and the digestibility of certain FAs. That peculiarity adds up to other characteristics of the mammary metabolism (shortchain FA synthesis, long-chain FA desaturation) towards lowering the melting point of milk fat and thus reducing the effects of rumen hydrogenation. The effects of dietary factors on the triglyceride molecular structure are still little-known.

\subsection{Lipid transformations in the rumen}

In the rumen lipids undergo high-intensity metabolism linked to microbial activity. Dietary FAs are strongly hydrogenated. Linoleic acid (cis9,cis12-18:2) is isomerised into rumenic acid (cis9,trans 11-18:2), then the latter is hydrogenated into vaccenic acid (trans 11-18:1) and eventually into stearic acid (C18:0). Linolenic acid induces a larger number of intermediaries, including vaccenic acid, but rumenic acid production does not seem to occur. In fact, biochemical pathways are much more complex. No less than twelve 18-carbon, mono-unsaturated isomers can be found in the rumen 


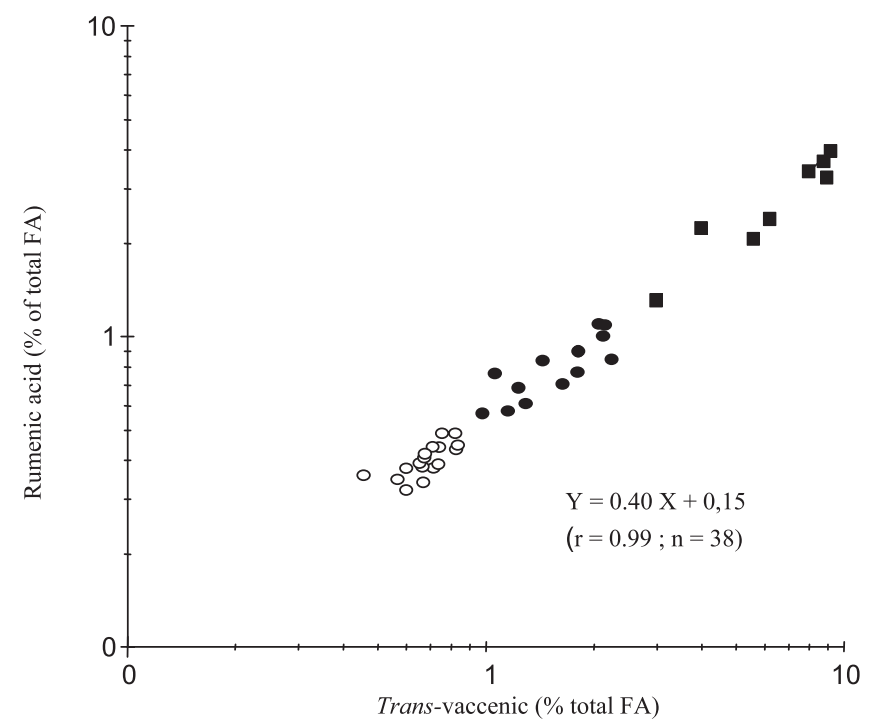

Figure 1. Relationship between the contents of trans-vaccenic and rumenic acids in goat milk. Each point is the mean of values from 7 to 16 goats $(\mathrm{N}=401$ milks from 38 experimental groups) (adapted from [7]). O Hay-based diets (either without lipid supplementation or with untreated lupin seeds or soybeans). $\bullet$ Hay-based diets (either without lipid supplementation or supplemented with high-oleic sunflower oil or untreated linseeds or sunflower seeds) or corn silage-based diets (either without lipid supplementation or with high-oleic sunflower oil). $\mathbf{\square}$ Hay or corn silage-based diets, supplemented with either linseed oil or sunflower oil.

medium [16] and many CLA isomers have been identified [17].

Indeed, the terms CLA (Conjugated Linoleic Acid) gather a large number of geometric and position isomers (all with conjugated double bonds) of linoleic acid. The hydrogenation of trans-18:1 classically constitutes the limiting step for the full hydrogenation of unsaturated C18, and trans-C18:1 frequently occurs in the rumen, contrarily to CLA [13]. A small proportion of the CLA produced by rumen PUFA hydrogenation is nonetheless absorbed in the intestine, taken up by the mammary gland and secreted in milk. However, rumenic acid synthesis mainly occurs (probably more than $75 \%$ ) in the udder, in proportion to the amount of vaccenic acid formed in the rumen (Fig. 1 and [18]).

The quantitative and qualitative balance of rumen metabolism has been described by Doreau and Ferlay [19]. Hydrogenation in the rumen averages $80 \%$ for linoleic acid and $92 \%$ for linolenic acid. The hydrogenation rate is mainly dependent on the proportion of concentrate in the diet. When it exceeds $70 \%$, hydrogenation only averages 50 and $65 \%$ for these two FAs. That phenomenon is related to a collapse in rumen $\mathrm{pH}$.

\section{CONTROLLING THE FA COMPOSITION OF MILK LIPIDS BY YHE NUTRITION OF DAIRY ANIMALS}

\subsection{Saturated fatty acids and oleic acid}

Most fatty acids originating from de novo lipogenesis are saturated (C4:0 to $\mathrm{C} 16: 0)$, because mammary delta- 9 desaturase is only weakly active on fatty acids with less than 18 carbon atoms. Long-chain FAs (at least 18 carbon atoms) are powerful inhibitors of 
acetyl-CoA carboxylase and of de novo lipogenesis in mammary cells. This effect is more marked when FAs have a long chain, are more unsaturated and contain more trans double bonds (review by Chilliard et al. [9]).

When the bioavailability of C18 FAs increases (as a result of either increased dietary intake or body lipid mobilization), C8:0 to C16:0 FA secretion decreases, and their concentration (Tabs. II-V) decreases even more through dilution in a larger quantity of long-chain FAs. Dietary FAs also have an indirect negative effect on mammary de novo lipogenesis because of the decreased intake of fermentable organic matter and hence production of volatile FAs, and of the lower acetate/propionate ratio in the rumen. These modifications indeed reduce acetate and 3-hydroxybutyrate bioavailability to mammary lipogenesis. The potential to decrease medium-chain saturated FAs (C10 to C16:0) is very large. For example, with hay-based diets, these FAs represented $59 \%$ of goat milk fat and decreased to $38 \%$ after linseed oil supplementation, or to $33 \%$ if vitamin $\mathrm{E}$ was added with linseed oil (Tab. V).

Pasture intake has effects close to those of 18-carbon-atom FA supplementation. Indeed, compared to grass silage-based diets, milk myristic and palmitic acid concentrations are reduced (review by Chilliard et al. [20]). Conversely, if lipid supplements contain mainly medium-chain fatty acids, these will be increased. Such is the case with palm oil calcium salts, which increase palmitic acid concentration $\left(+21 \mathrm{mg} \cdot \mathrm{g}^{-1}\right.$ for $770 \mathrm{~g} \cdot \mathrm{d}^{-1}$ mean supplementation over six trials). Such an effect is not beneficial to milk nutritional quality.

Contrary to medium-chain FAs, shortchain FA concentrations (C4:0, C6:0 and $\mathrm{C} 8: 0$ to a lesser extent) are classically either unchanged or only slightly reduced by increased lipid supplementation in the diet (Tabs. II-IV) or body lipid mobilization. That specificity is probably due to the fact that those fatty acids are partly synthesized by metabolic pathways not dependent on
acetyl-CoA carboxylase [21, 22]. The stability of butyric acid concentration in milk is interesting because that FA has beneficial effects on human health [23].

Stearic acid secretion in milk can be increased either by dietary stearic acid intake or by supplementation of C18 unsaturated FAs because they are in part hydrogenated into stearic acid in the rumen. The same applies to oleic acid either through its direct secretion or from its synthesis through the action of mammary desaturase on stearic acid. It is recommended to increase the $c i s 9$ 18:1/18:0 ratio to reduce butter firmness and improve its nutritional quality, so as to reduce atherogenous risks in man [1]. That ratio is regulated by the respective bioavailabilities of the two FAs, by mammary desaturase activity and by the modulating factors of that activity (PUFA or trans FAs availability in particular).

Among the dietary factors which alter the secretion of stearic and oleic acids in milk, tallow supplementation (rich in C16:0, C18:0 and cis9-18:1) has been extensively explored (review by Chilliard et al. [20]). It appears that tallow favourably modifies the nutritional quality of milk FAs by sharply reducing their atherogenicity index [24]. However, those supplements are now banned in Europe, in application of the principle of precaution with regard to the theoretical risks of prionic contamination.

Other ways to increase milk oleic acid secretion include the distribution of oleamides [25] or properly protected oleic-acidrich vegetable oils or seeds (oleic sunflower, rapeseed). When giving unprotected vegetable oils or seeds containing high levels of oleic, linoleic or linolenic acids, the absorbed fluxes of dietary oleic acid which escapes ruminal hydrogenation can be increased, although the main response is an increase in the stearic acid produced in the rumen, which is then transformed in part into oleic acid in the udder. Thus, the proportion of stearic acid and, sometimes, oleic acid are increased in milk (Tabs. II-V). For example, cow's milk oleic acid was multiplied by 
Table II. Effects of supplementation with oilseeds on milk yield, fat content and yield, and fatty acid composition in dairy cow ${ }^{1}$.

\begin{tabular}{|c|c|c|c|c|c|c|c|c|c|}
\hline \multirow[t]{2}{*}{ Supplement } & \multicolumn{2}{|c|}{ Linseed } & \multicolumn{2}{|c|}{ Sunflower (18:2-rich) } & \multicolumn{3}{|c|}{ Soybean } & \multicolumn{2}{|c|}{ Rapeseed } \\
\hline & $\mathrm{Oil}^{2}$ & Seed $^{3}$ & $\mathrm{Oil}^{2}$ & Seed $^{4}$ & $\mathrm{Oil}^{5}$ & Raw $^{6}$ & Extruded $^{7}$ & $\mathrm{Oil}^{8}$ & Seed $^{3}$ \\
\hline Dietary lipids (\%) & +3 & +2.5 & +3 & +4.2 & +2.3 & +2.8 & +1.8 & +2.1 & +2.3 \\
\hline Milk yield $\left(\mathrm{kg} \cdot \mathrm{d}^{-1}\right)$ & +1.5 & -1.7 & +2.2 & -2.5 & +1.5 & -0.3 & -0.2 & +0.8 & -0.9 \\
\hline Milk fat content $\left(\mathrm{g} \cdot \mathrm{kg}^{-1}\right)$ & -3.3 & +0.3 & -4.8 & -7.1 & -0.9 & -2.1 & +0.6 & -2.8 & -1.9 \\
\hline Milk fat yield $\left(\mathrm{g} \cdot \mathrm{d}^{-1}\right)$ & -47 & +30 & -57 & -259 & +10 & -40 & +10 & -70 & -30 \\
\hline \multicolumn{10}{|c|}{ Milk fatty acids ( $\%$ of total FA) } \\
\hline $\mathrm{C} 4: 0$ & -0.1 & $\mathrm{nd}^{9}$ & -0.2 & -1.2 & +0.5 & +0.3 & +0.1 & +0.4 & nd \\
\hline C6 to $\mathrm{C} 8: 0$ & -0.8 & -0.6 & -0.9 & -2.1 & -0.4 & -0.2 & -0.4 & -1.1 & -0.9 \\
\hline $\mathrm{C} 10$ to $\mathrm{C} 14: 0$ & -4.6 & -3.2 & -5.3 & -8.6 & -5.2 & -3.7 & -3.6 & -2.7 & -3.9 \\
\hline C16:0 & -9.6 & -3.2 & -9.9 & -8.7 & -5.1 & -7.5 & -5.4 & -10.7 & -4.0 \\
\hline C18:0 & +3.0 & +3.8 & +3.3 & +4.1 & +3.4 & +0.8 & +1.7 & +4.0 & +3.3 \\
\hline C18:1 & +7.1 & +4.0 & +9.2 & +15.8 & +6.3 & +7.9 & +4.6 & +13.6 & +5.7 \\
\hline C18:1 c9 & +4.0 & nd & +5.2 & $(+9.7)^{10}$ & nd & nd & +2.7 & +10.6 & nd \\
\hline C18:1 t11 & +3.1 & -0.4 & +4.0 & $(+7.4)^{10}$ & nd & nd & +1.4 & +3.0 & +0.02 \\
\hline $\mathrm{C} 18: 2$ c9 c12 & -0.1 & -0.7 & +0.4 & +1.3 & -1.0 & +0.9 & +1.9 & -0.1 & -0.8 \\
\hline C18:3 c9 c12 c15 & +0.2 & +0.8 & -0.1 & +0.3 & -0.04 & -0.1 & +0.3 & +0.3 & +0.02 \\
\hline C18:2 c9 t11 & +1.2 & -0.2 & +1.6 & nd & $(+1.7)^{11}$ & $(-0.02)^{11}$ & +0.5 & +0.6 & +0.01 \\
\hline
\end{tabular}

${ }^{1}$ Difference between fat supplemented and control groups.

2 A. Ferlay and Y. Chilliard, unpublished data, 47.5 or $59.8 \%$ silage, 12.9 or $4.7 \%$ grass hay, 36.7 or $32.4 \%$ concentrate, and $3 \%$ of oil for diets based on grass or maize silage, respectively.

3 [91] $43.9 \%$ alfalfa silage, $11.8 \%$ barley silage, $8.3 \%$ ground linseeds $(3.3 \%$ oil) or rapeseeds $(3.4 \%$ oil), and $36.0 \%$ concentrate.

4 [92] $40 \%$ maize silage, $15 \%$ alfalfa hay, $19 \%$ concentrate, and $21 \%$ of rolled sunflower seeds ( $9.8 \%$ oil).

5 [93] 30\% alfalfa silage, $20 \%$ maize silage, $47.7 \%$ concentrate, and $2.3 \%$ oil.

6 [94] $42 \%$ dehydrated alfalfa pellets and long alfalfa hay, 16\% maize silage, $14.7 \%$ ground raw soybeans ( $2.9 \%$ oil), $27.3 \%$ concentrate

7 [95] 25\% alfalfa silage, $25 \%$ maize silage, $39.4 \%$ concentrate, and $10.6 \%$ extruded soybeans ( $2.1 \%$ oil).

8 [96] $17.5 \%$ alfalfa haylage, $30.7 \%$ maize silage, $48.5 \%$ concentrate, and $3.3 \%$ oil.

${ }^{9} \mathrm{Nd}$, not determined.

10 All cis-18:1 or trans-18:1 isomers.

11 [97] 34\% alfalfa silage, $17 \%$ maize silage, 45.4 or $31.0 \%$ concentrate, and $3.6 \%$ soybean oil or $18 \%$ raw cracked soybeans ( $3.6 \%$ oil), for diets supplemented with oil or soybeans. 
Table III. Milk yield and composition in goats fed a low forage $\operatorname{diet}^{1}$, supplemented or not with oils or whole crude oilseeds during 11 weeks $^{2}$ ( 7 goats per group) (adapted from [7]).

\begin{tabular}{|c|c|c|c|c|c|c|c|}
\hline Diet & Control & $\begin{array}{c}\text { Linseed } \\
\text { oil }\end{array}$ & Linseeds & $\begin{array}{c}\text { Sunflower } \\
\text { oil }\end{array}$ & $\begin{array}{c}\text { Sunflower } \\
\text { seeds }\end{array}$ & $\begin{array}{c}\text { Lupine } \\
\text { seeds }\end{array}$ & Soybeans \\
\hline Milk yield ${ }^{3}\left(\mathrm{~kg} \cdot \mathrm{d}^{-1}\right)$ & 2.86 & 3.12 & 2.91 & 3.15 & 3.11 & 3.16 & 3.37 \\
\hline Fat content $\left(\mathrm{g} \cdot \mathrm{kg}^{-1}\right)$ & $25.5^{\mathrm{a}}$ & $28.6^{\mathrm{b}}$ & $31.5^{\mathrm{b}}$ & $30.7^{\mathrm{b}}$ & $31.3^{\mathrm{b}}$ & $29.2^{\mathrm{b}}$ & $29.6^{\mathrm{b}}$ \\
\hline Fat yield $\left(\mathrm{g} \cdot \mathrm{d}^{-1}\right)$ & $72^{\mathrm{a}}$ & $90^{\mathrm{b}}$ & $93^{\mathrm{b}}$ & $94^{\mathrm{b}}$ & $95^{\mathrm{b}}$ & $92^{\mathrm{b}}$ & $97^{\mathrm{b}}$ \\
\hline \multicolumn{8}{|c|}{ Fatty acids (w\% of total FA) } \\
\hline $\mathrm{C} 4+\mathrm{C} 6+\mathrm{C} 8$ & $7.9^{\mathrm{b}}$ & $7.5^{\mathrm{ab}}$ & $7.8^{\mathrm{b}}$ & $7.7^{\mathrm{b}}$ & $6.9^{\mathrm{a}}$ & $7.4^{\mathrm{ab}}$ & $7.1^{\mathrm{ab}}$ \\
\hline $\mathrm{C} 10+\mathrm{C} 12+\mathrm{C} 14$ & $24.9^{\mathrm{b}}$ & $16.3^{\mathrm{a}}$ & $18.0^{\mathrm{a}}$ & $17.3^{\mathrm{a}}$ & $16.9^{\mathrm{a}}$ & $18.6^{\mathrm{a}}$ & $16.9^{\mathrm{a}}$ \\
\hline C16:0 & $25.8^{\mathrm{c}}$ & $16.9^{\mathrm{a}}$ & $19.0^{\mathrm{b}}$ & $18.2^{\mathrm{ab}}$ & $18.7^{\mathrm{b}}$ & $19.4^{\mathrm{b}}$ & $19.6^{\mathrm{b}}$ \\
\hline C18:0 & $9.0^{\mathrm{a}}$ & $13.8^{\mathrm{b}}$ & $15.2^{\mathrm{bc}}$ & $13.0^{\mathrm{b}}$ & $15.9^{c}$ & $13.5^{\mathrm{b}}$ & $16.6^{\mathrm{c}}$ \\
\hline $\mathrm{C} 18: 1 \mathrm{t} 11$ & $0.95^{\mathrm{a}}$ & $2.92^{b c}$ & $1.28^{\mathrm{a}}$ & $3.94^{\mathrm{c}}$ & $2.30^{\mathrm{b}}$ & $0.66^{\mathrm{a}}$ & $0.85^{\mathrm{a}}$ \\
\hline C18:1 c9 & $19.1^{\mathrm{a}}$ & $22.6^{\mathrm{ab}}$ & $24.7^{\mathrm{bcd}}$ & $20.8^{\mathrm{a}}$ & $23.9^{b c}$ & $27.4^{\mathrm{d}}$ & $26.3^{\mathrm{cd}}$ \\
\hline $\mathrm{C} 18: 2 \mathrm{c} 9 \mathrm{c} 12$ & $2.2^{\mathrm{c}}$ & $2.2^{\mathrm{bc}}$ & $1.9^{\mathrm{b}}$ & $3.4^{\mathrm{e}}$ & $3.0^{\mathrm{d}}$ & $1.6^{\mathrm{a}}$ & $3.3^{\mathrm{de}}$ \\
\hline $\mathrm{C} 18: 3 \mathrm{c} 9 \mathrm{c} 12 \mathrm{c} 15$ & $0.41^{\mathrm{a}}$ & $1.68^{\mathrm{d}}$ & $1.24^{\mathrm{c}}$ & $0.49^{\mathrm{a}}$ & $0.51^{\mathrm{b}}$ & $0.63^{\mathrm{b}}$ & $0.40^{\mathrm{a}}$ \\
\hline $\mathrm{C} 18: 2 \mathrm{c} 9 \mathrm{t} 11$ & $0.56^{\mathrm{b}}$ & $1.38^{\mathrm{d}}$ & $0.60^{\mathrm{b}}$ & $2.28^{\mathrm{e}}$ & $0.84^{\mathrm{c}}$ & $0.28^{\mathrm{a}}$ & $0.40^{\mathrm{ab}}$ \\
\hline $\mathrm{AI}^{4}$ & $2.92^{\mathrm{c}}$ & $1.21^{\mathrm{a}}$ & $1.61^{\mathrm{b}}$ & $1.36^{\mathrm{a}}$ & $1.48^{\mathrm{ab}}$ & $1.72^{\mathrm{b}}$ & $1.52^{\mathrm{ab}}$ \\
\hline Desaturation index 5 & $0.69^{\mathrm{c}}$ & $0.63^{b}$ & $0.62^{\mathrm{ab}}$ & $0.61^{\mathrm{ab}}$ & $0.59^{\mathrm{a}}$ & $0.67^{\mathrm{c}}$ & $0.61^{\mathrm{ab}}$ \\
\hline
\end{tabular}

1 Natural grassland hay (30\%) and concentrates with or without oils or oilseeds $(70 \%)$.

$23.4 \pm 0.6 \%$ added lipid in DM intake (supplemented-control).

${ }^{3}$ Data in same row with similar superscript letters do not differ at $P<0.05$ level.

${ }^{4}$ Atherogenecity index, $(\mathrm{C} 12+4 \mathrm{C} 14+\mathrm{C} 16)$ :(sum of unsaturated FA).

${ }^{5}$ C18:1c9:(C18:0 + C18:1c9).

1.18 to 1.34 when adding either sunflower or linseed oil to the diet, and these responses were dose-dependent, and more marked with grass silage than maize silage diet (Fig. 2). Grazing is another way to increase stearic and oleic acid concentrations in cow milk. Oleic acid percentage in milk fat can increase from $14-18 \%$ with lipid-poor winter diets to $22-24 \%$ at pasture, which provides PUFA that can be hydrogenated in the rumen [26]

In goats, when comparing 26 diets combining different forages, concentrate percentages and lipid sources (Fig. 3), it appears that the highest milk oleic percentages (more than 24\% of total FA) are obtained either with unprotected high-oleic sunflower oil (and more with alfalfa hay or rye-grass than with maize silage) or with oilseeds, in the rank lupin $>$ soybean $>$ linseed $>$ sunflower. Beside the direct absorption of die- tary oleic acid, these results arise also from the absorption of stearic acid yielded from oleic acid in the rumen, and then its delta 9-desaturation in the mammary gland. It can be observed that the cis9-18:1/18:0 ratio is decreased by lipid supplements: more markedly by oilseeds than oil, and more markedly by PUFA-rich oils than high-oleic oil (Fig. 4 and Tab. V). This ratio is further decreased when vitamin $E$ is added to the diet (Tab. V). All together, these results suggest that the desaturation ratio of stearic acid in the mammary gland is decreased by diets which increase the availability of either PUFAs or trans-FAs (see Tabs. III-V), as these FAs are putative inhibitors of the delta9-desaturase [27-29].

The case of lupine seeds is interesting because this seed, rich in 18:1 and 18:2, is the only one which did not decrease the 
Table IV. Interactions between forage nature and vegetable oil supplementation (5-6\% of diet DM) on goat milk yield and composition (adapted from [81])1.

\begin{tabular}{|c|c|c|c|c|c|c|}
\hline \multirow{2}{*}{$\begin{array}{l}\text { Forage } \\
\text { Oil }\end{array}$} & \multicolumn{3}{|c|}{ Maize silage } & \multicolumn{3}{|c|}{ Alfalfa hay } \\
\hline & $\mathrm{C}^{2}$ & LO & OSO & $\mathrm{C}^{3}$ & LO & OSO \\
\hline Milk yield $\left(\mathrm{kg} \cdot \mathrm{d}^{-1}\right)$ & 3.62 & 3.95 & 3.61 & 3.65 & 3.61 & 3.54 \\
\hline Fat content $\left(\mathrm{g} \cdot \mathrm{kg}^{-1}\right)$ & $33.4^{\mathrm{b}}$ & $33.4^{\mathrm{b}}$ & $36.3^{\mathrm{bc}}$ & $29.7^{\mathrm{a}}$ & $36.9^{\mathrm{c}}$ & $35.1^{\mathrm{bc}}$ \\
\hline Fat yield $\left(\mathrm{g} \cdot \mathrm{d}^{-1}\right)$ & $121^{\mathrm{ab}}$ & $129^{\mathrm{a}}$ & $132^{\mathrm{a}}$ & $108^{\mathrm{b}}$ & $134^{\mathrm{a}}$ & $123^{\mathrm{ab}}$ \\
\hline \multicolumn{7}{|c|}{ Fatty acids (w\% of total FA) } \\
\hline $\mathrm{C} 4: 0$ & $2.2^{\mathrm{ab}}$ & $2.8^{\mathrm{d}}$ & $2.6^{\mathrm{cd}}$ & $2.2^{\mathrm{ab}}$ & $2.4^{\mathrm{bc}}$ & $2.2^{\mathrm{ab}}$ \\
\hline C6:0 & $2.5^{\mathrm{bc}}$ & $2.6^{\mathrm{c}}$ & $2.4^{\mathrm{bc}}$ & $2.3^{\mathrm{b}}$ & $2.1^{\mathrm{ab}}$ & $2.1^{\mathrm{ab}}$ \\
\hline $\mathrm{C} 8: 0$ & $2.8^{\mathrm{d}}$ & $2.6^{\mathrm{cd}}$ & $2.4^{\text {bcd }}$ & $2.4^{\mathrm{b}}$ & $2.0^{\mathrm{a}}$ & $2.0^{\mathrm{ab}}$ \\
\hline C10:0 & $10.0^{\mathrm{c}}$ & $8.1^{\mathrm{ab}}$ & $7.4^{\mathrm{a}}$ & $8.8^{\mathrm{b}}$ & $6.1^{\mathrm{a}}$ & $6.5^{\mathrm{a}}$ \\
\hline $\mathrm{C} 12: 0$ & $4.7^{\mathrm{b}}$ & $3.0^{\mathrm{a}}$ & $3.0^{\mathrm{a}}$ & $4.6^{\mathrm{b}}$ & $2.7^{\mathrm{a}}$ & $2.9^{\mathrm{a}}$ \\
\hline $\mathrm{C} 14: 0$ & $11.7^{\mathrm{c}}$ & $8.2^{\mathrm{b}}$ & $8.4^{\mathrm{b}}$ & $12.2^{\mathrm{c}}$ & $7.6^{\mathrm{a}}$ & $8.4^{\mathrm{b}}$ \\
\hline C16:0 & $28.8^{\mathrm{b}}$ & $18.5^{\mathrm{a}}$ & $18.7^{\mathrm{a}}$ & $31.1^{\mathrm{c}}$ & $18.2^{\mathrm{a}}$ & $17.8^{\mathrm{a}}$ \\
\hline $\mathrm{C} 18: 0$ & $7.5^{\mathrm{b}}$ & $9.5^{\mathrm{c}}$ & $13.8^{\mathrm{b}}$ & $6.0^{\mathrm{a}}$ & $10.8^{\mathrm{d}}$ & $12.7^{\mathrm{e}}$ \\
\hline $\mathrm{C} 18: 1 \mathrm{t} 10$ & $0.24^{\mathrm{a}}$ & $2.97^{\mathrm{c}}$ & $2.20^{\mathrm{c}}$ & $0.07^{\mathrm{a}}$ & $0.29^{\mathrm{a}}$ & $0.70^{b}$ \\
\hline $\mathrm{C} 18: 1 \mathrm{t} 11$ & $1.18^{\mathrm{ab}}$ & $6.18^{c}$ & $1.88^{\mathrm{ab}}$ & $0.45^{\mathrm{a}}$ & $8.80^{\mathrm{d}}$ & $2.12^{\mathrm{b}}$ \\
\hline $\mathrm{C} 18: 1 \mathrm{c} 9$ & $15.7^{\mathrm{ab}}$ & $14.2^{\mathrm{a}}$ & $23.5^{\mathrm{c}}$ & $16.6^{\mathrm{b}}$ & $15.6^{\mathrm{ab}}$ & $27.7^{\mathrm{d}}$ \\
\hline $\mathrm{C} 18: 2 \mathrm{c} 9 \mathrm{c} 12$ & $2.0^{\mathrm{d}}$ & $1.5^{\mathrm{b}}$ & $1.4^{\mathrm{a}}$ & $2.3^{\mathrm{e}}$ & $1.7^{\mathrm{c}}$ & $1.6^{\mathrm{b}}$ \\
\hline $\mathrm{C} 18: 3 \mathrm{c} 9 \mathrm{c} 12 \mathrm{c} 15$ & $0.32^{\mathrm{b}}$ & $0.69^{\mathrm{d}}$ & $0.17^{\mathrm{a}}$ & $0.60^{\mathrm{d}}$ & $1.37^{\mathrm{e}}$ & $0.42^{\mathrm{c}}$ \\
\hline $\mathrm{C} 18: 2 \mathrm{c} 9 \mathrm{t} 11$ & $0.59^{\mathrm{ab}}$ & $2.42^{\mathrm{c}}$ & $0.80^{\mathrm{ab}}$ & $0.33^{\mathrm{a}}$ & $3.22^{\mathrm{d}}$ & $1.02^{\mathrm{b}}$ \\
\hline Desaturation index ${ }^{4}$ & $0.67^{\mathrm{c}}$ & $0.61^{\mathrm{ab}}$ & $0.63^{\mathrm{b}}$ & $0.73^{\mathrm{d}}$ & $0.59^{\mathrm{a}}$ & $0.68^{\mathrm{c}}$ \\
\hline
\end{tabular}

${ }^{1} \mathrm{C}, \mathrm{LO}, \mathrm{OSO}=$ control, linseed oil, oleic sunflower oil, respectively; twelve goats per group, except haycontrol group $(n=10)$; results obtained after 5 weeks of lipid supplementation.

2 Including $48 \%$ of concentrates.

${ }^{3}$ Including $44 \%$ of concentrates.

${ }_{4}^{4}$ 18:1c9:(C18:0 + C18:1c9); data in same row with similar superscript letters do not differ at $P<0.05$ level.

desaturation ratio (Fig. 4B), and which did not increase (or even decreased) goat milk PUFAs and vaccenic acid (Tab. III), suggesting that its unsaturated FAs where totally hydrogenated, despite the fact it was consumed as crude whole seed. Conversely, either linseed oil or extruded linseeds supplementations decreased strongly the desaturation ratio, simultaneously to the high increases in both 18:3n-3 and trans-FAs percentages in milk fat (Fig. 4 and Tab. V).

\subsection{Polyunsaturated fatty acids}

PUFAs are not synthesized by tissues in ruminants, therefore their concentration in milk is closely related to the quantities absorbed in the intestine, hence the quantities leaving the rumen. Those quantities may be increased by dietary PUFA intake and by factors which decrease rumen hydrogenation, such as fatty acid trapping in vegetable cells, high forage/concentrate ratio or the implementation of PUFA-rich oil encapsulation techniques.

\subsubsection{Linoleic acid (n-6 series)}

With most non lipid-added diets, the proportion of linoleic acid in milk fatty acids is classically between 2 and $3 \%$. When rations are supplemented with linoleic acid-rich seeds 
Table V. Effects of linseed oil, vitamin E or extruded linseed supplementations on milk fatty acid composition in goats receiving during 5 weeks diets with either high or low forage:concentrate ratio ${ }^{1}$.

\begin{tabular}{|c|c|c|c|c|c|c|c|c|c|c|}
\hline \multirow{2}{*}{$\begin{array}{c}\text { Supplement }^{2} \\
\text { F: } \mathrm{C}^{4}\end{array}$} & \multicolumn{2}{|c|}{ No supplement } & \multicolumn{2}{|c|}{ Linseed oil (LO) } & \multicolumn{2}{|c|}{$\mathrm{LO}+$ vitamin $\mathrm{E}$} & \multirow{2}{*}{$\begin{array}{l}\text { ELS }^{3} \\
\text { High }\end{array}$} & \multicolumn{3}{|c|}{ Statistical effects $(P<)$} \\
\hline & High & Low & High & Low & High & Low & & $\mathrm{F}: \mathrm{C}(n=72)$ & $\mathrm{LO}(n=48)$ & Vit $\mathrm{E}(n=48)^{8}$ \\
\hline Milk yield $\left(\mathrm{kg} \cdot \mathrm{d}^{-1}\right)$ & $4.26^{\mathrm{a}}$ & $4.39^{\mathrm{ab}}$ & $4.25^{\mathrm{a}}$ & $4.28^{\mathrm{a}}$ & $4.19^{\mathrm{a}}$ & $4.74^{\mathrm{b}}$ & $4.26^{\mathrm{a}}$ & 0.08 & NS & NS \\
\hline Fat content $\left(\mathrm{g} \cdot \mathrm{kg}^{-1}\right)$ & $28.1^{\mathrm{a}}$ & $27.0^{\mathrm{a}}$ & $33.2^{\mathrm{b}}$ & $33.3^{\mathrm{b}}$ & $34.9^{\mathrm{b}}$ & $34.8^{\mathrm{b}}$ & $35.4^{\mathrm{b}}$ & NS & 0.001 & NS \\
\hline Fat yield $\left(\mathrm{g} \cdot \mathrm{d}^{-1}\right)$ & $119^{\mathrm{a}}$ & $120^{\mathrm{a}}$ & $140^{\mathrm{ab}}$ & $141^{\mathrm{b}}$ & $149^{\mathrm{bc}}$ & $166^{\mathrm{c}}$ & $150^{\mathrm{bc}}$ & NS & 0.001 & 0.07 \\
\hline \multicolumn{11}{|c|}{ Milk fatty acids ( $\%$ of total FA) } \\
\hline $\mathrm{C} 10+\mathrm{C} 12+\mathrm{C} 14$ & $26.8^{\mathrm{e}}$ & $29.2^{\mathrm{f}}$ & $19.0^{\mathrm{bc}}$ & $22.7^{\mathrm{d}}$ & $16.1^{\mathrm{a}}$ & $20.2^{c}$ & $18.8^{\mathrm{b}}$ & 0.003 & 0.001 & 0.001 \\
\hline C16:0 & $31.9^{d}$ & $27.4^{\mathrm{c}}$ & $18.7^{b}$ & $19.8^{\mathrm{b}}$ & $16.9^{\mathrm{a}}$ & $18.8^{\mathrm{b}}$ & $17.2^{\mathrm{a}}$ & NS & $0.001^{7}$ & 0.001 \\
\hline C18:0 & $6.3^{\mathrm{a}}$ & $6.1^{\mathrm{a}}$ & $9.8^{\mathrm{c}}$ & $8.6^{\mathrm{b}}$ & $10.9^{\mathrm{d}}$ & $9.3^{\mathrm{bc}}$ & $11.3^{\mathrm{d}}$ & 0.04 & 0.001 & 0.001 \\
\hline $\mathrm{C} 18: 1 \mathrm{t} 10$ & $0.12^{\mathrm{a}}$ & $0.33^{\mathrm{ab}}$ & $0.43^{\mathrm{ab}}$ & $1.00^{\mathrm{c}}$ & $0.57^{\mathrm{b}}$ & $1.06^{\mathrm{c}}$ & $0.59^{\mathrm{b}}$ & 0.005 & $0.001^{7}$ & NS \\
\hline C18:1 t11 & $0.54^{\mathrm{a}}$ & $1.27^{\mathrm{a}}$ & $7.78^{\mathrm{c}}$ & $7.36^{\mathrm{bc}}$ & $9.52^{\mathrm{d}}$ & $8.15^{\mathrm{c}}$ & $6.48^{\mathrm{b}}$ & NS & $0.001^{7}$ & 0.005 \\
\hline $\mathrm{C} 18: 1 \mathrm{c} 9$ & $14.9^{\mathrm{b}}$ & $14.4^{\mathrm{ab}}$ & $15.0^{\mathrm{b}}$ & $13.3^{\mathrm{a}}$ & $14.9^{\mathrm{b}}$ & $13.3^{\mathrm{a}}$ & $14.6^{\mathrm{b}}$ & 0.001 & NS & NS \\
\hline $\mathrm{C} 18: 2 \mathrm{c} 9 \mathrm{t} 13$ & $0.10^{\mathrm{a}}$ & $0.22^{\mathrm{b}}$ & $0.50^{\mathrm{de}}$ & $0.41^{\mathrm{c}}$ & $0.54^{\mathrm{ef}}$ & $0.48^{\mathrm{d}}$ & $0.59^{f}$ & NS & $0.001^{7}$ & 0.002 \\
\hline $\mathrm{C} 18: 2 \mathrm{c} 9 \mathrm{c} 12$ & $2.4^{\mathrm{c}}$ & $2.8^{\mathrm{d}}$ & $1.8^{\mathrm{a}}$ & $1.8^{\mathrm{ab}}$ & $1.8^{\mathrm{ab}}$ & $1.8^{\mathrm{a}}$ & $2.0^{\mathrm{b}}$ & NS & $0.001^{7}$ & NS \\
\hline C18:2 t11 c15 & $0.01^{\mathrm{a}}$ & $0.01^{\mathrm{a}}$ & $1.96^{\mathrm{b}}$ & $1.82^{\mathrm{b}}$ & $2.22^{\mathrm{c}}$ & $2.32^{\mathrm{c}}$ & $1.83^{\mathrm{b}}$ & NS & 0.001 & 0.004 \\
\hline $\mathrm{C} 18: 3 \mathrm{c} 9 \mathrm{c} 12 \mathrm{c} 15$ & $0.78^{b}$ & $0.43^{\mathrm{a}}$ & $1.69^{\mathrm{d}}$ & $1.08^{\mathrm{c}}$ & $1.74^{\mathrm{d}}$ & $1.19^{\mathrm{c}}$ & $2.66^{\mathrm{e}}$ & 0.001 & $0.001^{7}$ & NS \\
\hline $\mathrm{C} 18: 2 \mathrm{c} 9 \mathrm{t} 11$ & $0.30^{\mathrm{a}}$ & $0.70^{\mathrm{a}}$ & $3.05^{\mathrm{c}}$ & $3.33^{\mathrm{c}}$ & $3.25^{\mathrm{c}}$ & $3.08^{c}$ & $2.09^{\mathrm{b}}$ & NS & 0.001 & NS \\
\hline $\mathrm{C} 18: 2 \mathrm{c} 9 \mathrm{c} 11+\mathrm{t} 11 \mathrm{c} 13$ & $0.04^{\mathrm{a}}$ & $0.03^{\mathrm{a}}$ & $0.87^{\mathrm{d}}$ & $0.57^{\mathrm{bc}}$ & $1.13^{\mathrm{e}}$ & $0.76^{\mathrm{cd}}$ & $0.40^{\mathrm{b}}$ & 0.09 & $0.001^{7}$ & 0.005 \\
\hline Sum of trans $F A^{5}$ & $1.42^{\mathrm{a}}$ & $3.30^{\mathrm{b}}$ & $15.57^{\mathrm{d}}$ & $15.67^{\mathrm{d}}$ & $18.35^{\mathrm{e}}$ & $16.78^{\mathrm{d}}$ & $13.51^{\mathrm{c}}$ & NS & $0.001^{7}$ & 0.003 \\
\hline Desaturation index ${ }^{6}$ & $0.70^{\mathrm{c}}$ & $0.71^{\mathrm{c}}$ & $0.60^{\mathrm{b}}$ & $0.61^{\mathrm{b}}$ & $0.58^{\mathrm{a}}$ & $0.58^{\mathrm{ab}}$ & $0.56^{\mathrm{a}}$ & NS & 0.001 & 0.008 \\
\hline
\end{tabular}

17 groups of 12 goats. Adapted from [98-100]

${ }^{2}$ Linseed oil at $4.4 \%$ of diet DM; vitamin E at $1250 \mathrm{IU} / \mathrm{d} / \mathrm{goat}$.

${ }^{3}$ Extruded linseeds: extruded mixture (70/30) of linseeds and wheat (i.e. $4.3 \%$ linseed oil in diet DM).

${ }^{4}$ Forage: concentrate ratio. High $=70 \%$ alfalfa hay, $8 \%$ starch; Low $=46 \%$ alfalfa hay, $29 \%$ starch.

${ }^{5} \mathrm{C} 18: 1$ or $\mathrm{C} 18: 2$ with at least one trans double bond.

${ }^{6} \mathrm{C} 18: 1 \mathrm{c} 9:(\mathrm{C} 18: 0+\mathrm{C} 18: 1 \mathrm{c} 9)$

${ }^{7} \mathrm{~F}: \mathrm{C}-\mathrm{LO}$ interaction $(P<0.05)$.

${ }^{8}$ No interaction with F:C (in presence of LO).

a,b,c,d,e,f Data in same row with similar superscript letters do not differ at $P<0.05$ level. 


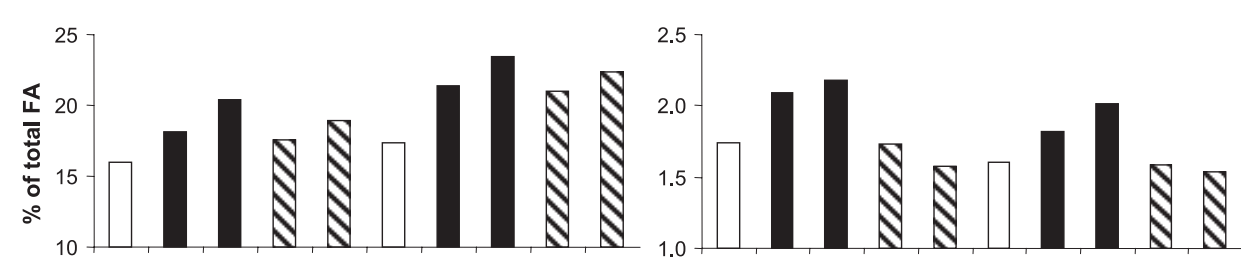

cis $9, \operatorname{cis} 12, \operatorname{cis} 15-18: 3$

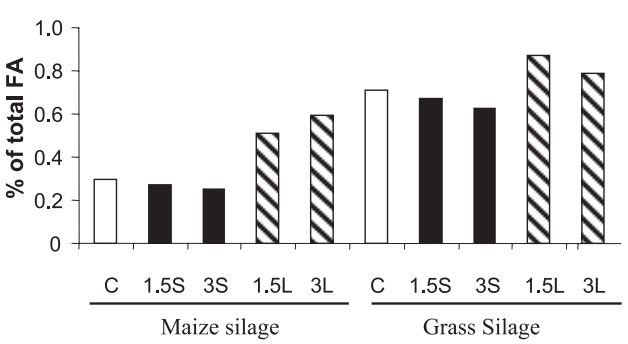

cis9,trans 11-18:2

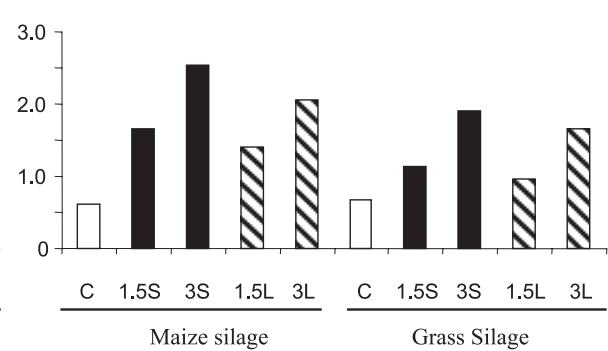

Figure 2. Effect of nature of forage, and nature and dose of oil supplement on milk percentages of cis $9-18: 1$, cis 9 ,cis $12-18: 2$, cis9, cis 12 , cis $15-18: 3$ and cis9,trans $11-18: 2$ in dairy cows (A. Ferlay and Y. Chilliard, unpublished data). Abbreviations used: $\mathrm{C}$, control (no oil); $1.5 \mathrm{~S}$ or 3S, diet supplemented with 1.5 or $3 \%$ of sunflower oil $(18: 2$-rich); $1.5 \mathrm{~L}$ or $3 \mathrm{~L}$, diet supplemented with 1.5 or $3 \%$ of linseed oil (18:3-rich) (20 cows were used in 2 replicated $5 \times 5$ Latin Square designs with 3 -week periods; maize or grass silage diets contained 13 or $5 \%$ grass hay, and 40 or $35 \%$ concentrates, respectively). Milk fat content $\left(\mathrm{g} \cdot \mathrm{kg}^{-1}\right)$ was $39,35,32,37,34,37,37,35,37,36$ for the 10 groups, as presented from left to right.

or oils like soybean or sunflower, that proportion rarely exceeds control values by more than $1.5 \%$ (Tabs. II and III).

It has often been suggested that giving lipids in the form of seeds rather than oil would limits rumen hydrogenation because seed sheaths would restrict bacterial access to lipids. For example, with soybean, it would limit the reduction of the acetate/propionate ratio in rumen volatile fatty acids [30] such a reduction often being generated by unsaturated lipid supplementation. Furthermore, raw or processed soybean at low doses, or sunflower seed at large doses do not reduce largely cow milk lipid secretion (Tab. I) and increase linoleic acid concentration to some extent (Tab. II). Further- more, direct comparison showed that extruded soybean increased less C18:2n-6 than raw soybean [31], probably because extrusion enhanced oil release from vegetable structures, enhancing their gradual hydrogenation. However, rapeseed sheaths appear to have a less protective effect than soybean or sunflower ones on milk fat content (Tab. I) and C18:2n-6 percentage (Tab. II). Additional research is necessary to confirm such trends because there are few direct comparisons between oil and seeds. Comparing sunflower oil and seeds in goats revealed that seed C18:2 was, paradoxically, more strongly hydrogenated to stearic acid than oil C18:2, found either intact or in the form of trans FA and CLA in milk (Tab. III). It 

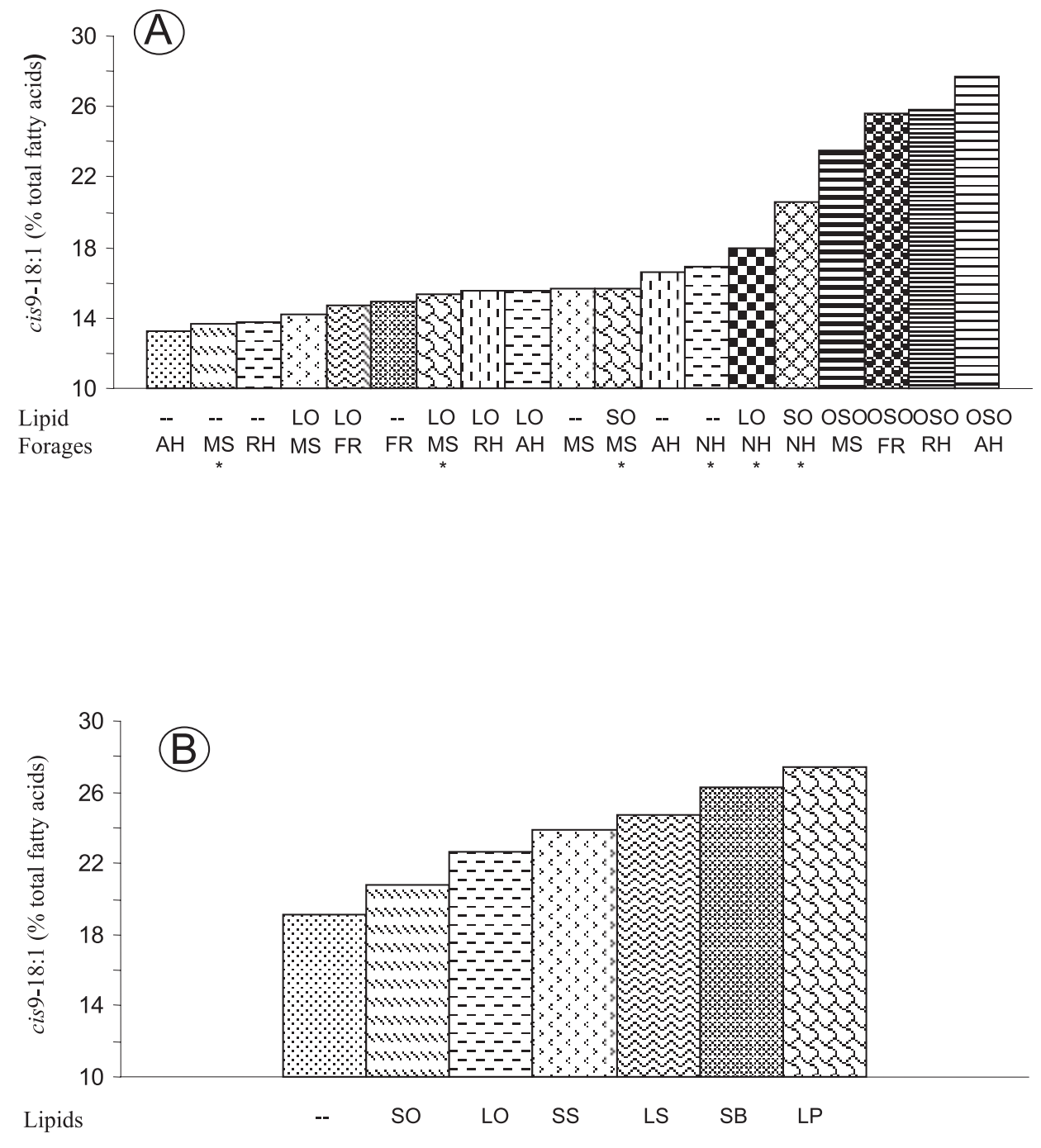

Figure 3. Forage-oil interactions on milk fat oleic acid percentage. (A) in goats receiving mediumconcentrate (45-60\% of diet DM) diets supplemented, or not, with oil (5-6\% of diet DM) during $3(*)-5$ weeks (10-14 goats per group; 181 goats) (adapted from [7, 15, 81, 82, 83, 108], (B) in goats receiving high-concentrate (70\% of diet DM) diet supplemented, or not, with oil or whole crude oilseeds (3.4\% of oil in diet DM) during 11 weeks (7 goats per group, 49 goats) (adapted from [7]). Forages: $\mathrm{AH}$, alfalfa hay; FR, fresh green rye-grass; $\mathrm{NH}$, natural grassland hay; MS, maize silage; RH, rye-grass hay. Lipids: - -, control diet (without oil addition); LO, linseed oil; LP, lupine seeds; LS, linseeds; OSO, high-oleic sunflower oil; SB, soybeans; SO, sunflower oil; SS, sunflower seeds. 

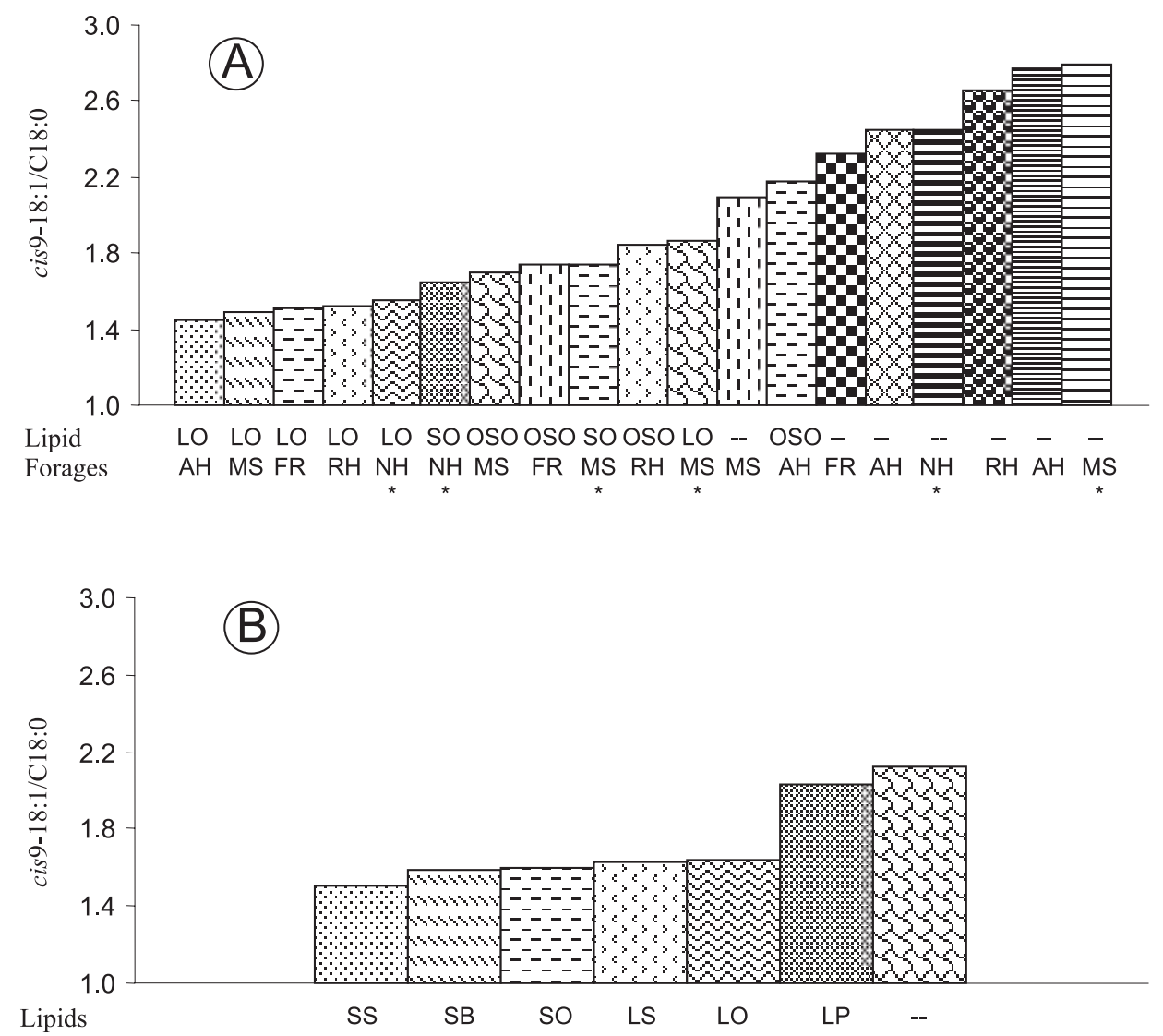

Figure 4. Forage-oil interactions on milk fat oleic:stearic ratio. (A) in goats receiving mediumconcentrate $(45-60 \%$ of diet DM) diets supplemented, or not, with oil (5-6\% of diet DM) during $3(*)-5$ weeks (10-14 goats per group; 181 goats) (adapted from [7, 15, 81, 82, 83, 108]), (B) in goats receiving high-concentrate $(70 \%$ of diet $\mathrm{DM})$ diet supplemented, or not, with oil or whole crude oilseeds (3.4\% of oil in diet DM) during 11 weeks (7 goats per group, 49 goats) (adapted from [7]). Forages: AH, alfalfa hay ; FR, fresh green rye-grass; NH, natural grassland hay; MS, maize silage; RH, rye-grass hay. Lipids: - -, control diet (without oil addition); LO, linseed oil; LP, lupine seeds; LS, linseeds; OSO, high-oleic sunflower oil; SB, soybeans; SO, sunflower oil; SS, sunflower seeds.

may therefore be supposed that the slow release of seed lipids enhances their total hydrogenation, at least in goats. A similar observation was made with C18:2-rich lupin seed, which strongly increased stearic and oleic acids while reducing milk C18:2n-6 and CLA (Tab. III).

Lipid supplements can be protected from rumen degradation by their encapsulation in a tanned-protein layer. Fifteen to $20 \%$ proportions of linoleic acid in milk fatty acids have been reached with encapsulated soybean, rapeseed, cotton, safflower or sunflower oil supplements [32]. The limitations of such a dietary practice is linked to the processing cost and to the controversial use of formaldehyde. Other lipid protection techniques, such as FA salts, do not prevent 
polyunsaturated FA hydrogenation $[33,34]$ or the negative effect of rapeseed oil on milk fat content (Tab. I), because the salts are dissociated in the rumen as the $\mathrm{pH}$ decreases.

The addition of linseed oil (18:3-rich) to cow's or goat's diet decreased milk linoleic acid percentage, probably because it increased linolenic percentage (Fig. 2 and Tabs. IV and V). Opposite responses between these 2 PUFAs were also observed when sunflower oil (18:2-rich) was added (Fig. 2). This illustrates that the different PUFAs are not secreted independently from each others. Lastly, it is worth reminding that increasing the linoleic acid proportion in dairy products is not a target in itself, insofar as improving the nutritional value of those products first requires to increase the linolenic/linoleic ratio.

\subsubsection{Linolenic acid and n-3 fatty acids}

Fresh green grass is the main source of alpha-linolenic acid, which explains why milk produced from grass-based diets contain more C18:3 n-3 than maize-based or concentrate-rich ones ([20, 26], Fig. 2 and Tabs. IV and V). However, hay making considerably reduces linolenic acid concentration in forage, as a result from concomitant decreases in FA and linolenic acid concentrations, whereas silage-related modifications are of lower extent [35]. It is mainly in the Spring and in the Autumn that FA contents and C18:3 n-3 concentrations are the highest in grass [36]. That explains the sharp increase in milk linolenic acid induced by turning out to pasture, which can be as high as $2.5 \%$ of total FAs [37,38]. However, concentrations not exceeding $1 \%$ have sometimes been noted in milk from pasture-fed cows $[6,39]$, probably when vegetation stage advances.

Apart from forage, only linseed provides very high linolenic acid levels, representing more than $50 \%$ of FAs. For example, a cow eating $20 \mathrm{~kg}$ DM per day on a spring or autumn sward may ingest up to $400 \mathrm{~g}$ lino- lenic acid per day, a similar amount to that provided by a winter ration with $3.7 \%$ linseed oil (or 12\% linseed) addition. Rapeseed contains a significant amount of linolenic acid, some of which is probably secreted in milk. However, as noted with C18:2, rapeseed oil or seed addition does not increase milk C18:3 any significantly (Tab. II).

Few trials have been conducted, where cows' diets were supplemented with linseed oil or seeds. Kennelly [40] noted an increase in milk linolenic acid concentration by $6 \mathrm{mg} \cdot \mathrm{g}^{-1}$ of total FAs. Other authors found either no increase [41] or increases in the range $3-8 \mathrm{mg} \cdot \mathrm{g}^{-1}$ ([42-44], Tab. II). Response to linseed oil, however, is stronger with a high-concentrate diet $\left(9 \mathrm{mg} \cdot \mathrm{g}^{-1}\right)$ than with a high-hay diet $\left(3 \mathrm{mg} \cdot \mathrm{g}^{-1}\right)$ ([14] and Loor et al. unpublished). The variability of the results obtained requires new studies by discriminating between the effects of oil and seeds, in particular. Table II results nonetheless suggest that ground linseeds do not increase milk C18:3 much more than linseed oil. The reverse has even been observed in goats, where $\mathrm{C} 18: 3$ from whole crude linseeds was more widely hydrogenated to C18:0 than C18:3 from free oil (Tab. III), as previously observed with sunflower C18:2. In other respects, linseed oil C18:3 seems to be less hydrogenated when given to goats receiving a hay-based than either a maize silage-based diet (Tab. IV) or a mediumconcentrate + hay diet (Tab. V).

The intake of $200-400 \mathrm{~g} \cdot \mathrm{d}^{-1}$ of linolenic acid from extruded rapeseeds and/or linseeds increased cow milk fat linolenic acid percentage by $3-6 \mathrm{mg} \cdot \mathrm{g}^{-1}[45,46]$, i.e. in the range observed with unprocessed linseeds or oil. The response to extruded linseeds seems to be however different in the goat (Tab. V), where linolenic acid increased more (+19 $\left.\mathrm{mg} \cdot \mathrm{g}^{-1}\right)$ than after linseed oil supplementation $\left(+9 \mathrm{mg} \cdot \mathrm{g}^{-1}\right)$. This high response of the goat milk 18:3 to extruded linseeds confirms previous results suggested by a comparison between extruded rapeseeds and linseeds [47]. 
As with linoleic acid-rich oil supplements, linseed oil protection by encapsulation is the only way to warrant very high linolenic concentration in milk. For instance, a $64 \mathrm{mg} \cdot \mathrm{g}^{-1}$ of linolenic acid in cow milk fat has been achieved by supplementing $410 \mathrm{~g}$ protected linseed oil per day [48]. Mere formaldehyde treatment of linseed increased goat milk C18:3 concentration more than untanned seed (+11 vs. $+6 \mathrm{mg} \cdot \mathrm{g}^{-1}$, [7], Chilliard et al. unpublished) but not beyond the effect of a similar dose of unprotected oil (+13 mg. $\mathrm{g}^{-1}$, Tab. III). However, formaldehyde treated linseeds did not increase [49] or very slightly increased [44] cow milk 18:3n-3 when compared to untreated seeds, thus confirming that cow is less responsive than goat.

One main factor that may restrict the use of linseeds in dairy cows' diet is its highly negative effect on vegetable wall digestion, combined with a sharp decrease in protozoa count and a trend of the VFA curve towards propionate [30]. However, all the digestive data were collected from sheep at maintenance receiving linseed oil. On the contrary, in productive dairy cattle zootechnical results indicate that linseed lipid supplementation does not induce any noticeable reduction of the energy and dairy value of the rations (Tabs. I and II); it has been recently verified also that the digestibility of maize silagebased (Ferlay et al., unpublished) or haybased [50] rations in dairy cows was not affected by linseed oil supplementation.

The secretion of long-chain FAs of the n-3 series (C20:5 or EPA, and C22:6 or DHA, respectively) may be increased when marine oils (fish or algae) are added to cows' rations (review by Chilliard et al. [20]). The effectiveness of the transfer from diet to milk, however, is low (2.6\% for EPA and $4.1 \%$ for DHA) because of high rumen hydrogenation, with EPA in particular. Higher transfer effectiveness between 16 and $33 \%$, have been noted during post-rumen infusion of fish oil. The increase in EPA + DHA concentrations in milk FAs is therefore mini- mal when fish oil is added to the cows' ration and rarely exceeds $0.5 \%$ of total FAs.

\subsection{Trans fatty acids and conjugated linoleic acid (CLA)}

\subsubsection{Effects on mammary lipogenesis}

Low dose marine oil supplementation induces a sharp decrease in milk fat content and secretion (Tab. I). That phenomenon could be linked to trans FA synthesis in the rumen and their inhibitory effect on mammary lipogenesis [20]. Milk fat content is otherwise sharply decreased by low-fiber and high-starch diets and/or by the administration of unprotected, unsaturated vegetable oils. The involvement of trans-18:1 in that decrease has long been suggested [51]. Griinari et al. [52] later showed the importance of the interaction of starch, fibre and PUFA contents in the diet.

The results in Table II also show that linseeds and rapeseeds reduce cow's mammary lipid secretion, and increase percentage of trans-18:1 in milk fat, less than their oil counterparts. It thus appears that hydrogenation is more complete (although it may sometimes involve a lower proportion of added PUFAs) when lipids are provided in seeds, probably because their gradual release does not affect the ecosystem of the rumen as much as oil supplementation in two meals per day (see also [53]). Direct oil/seed comparisons in goat (Tab. III) have confirmed those hypotheses, which are also in agreement with the decrease in the yield of trans$18: 1$, that has been observed when oil supplementation to dairy cow was broken down in 24 meals compared to 2 meals per day [54]. However, when a very large amount of sunflower seeds was added to a maize silage-rich diet, cow milk fat yield decreased and trans-18:1 percentage increased largely (Tab. II).

Nevertheless, in certain studies, an increase in the proportion of total trans-18:1 in milk was not accompanied by a lower milk fat yield. This has been better understood since 
the studies conducted by Piperova et al. [55], and other studies reviewed by Bauman and Griinari [56], which showed that low fiber diets supplemented with PUFA-rich plant oil sharply reduced mammary lipid secretion and strongly increased the proportions of trans 10-18:1 and to a certain extent, of trans 10,cis 12-18:2. It is therefore possible that trans 10, cis 12-18:2 results from rumen biohydrogenation modifications induced by low-fiber diets and is one of the precursors of the trans 10-18:1 yielded in the rumen. It is worth noting that under such conditions, vaccenic and rumenic acid syntheses only increased slightly by comparison with what happened with high-fiber diets supplemented with oil [57] or with low-fiber diets supplemented with oil and vitamin E [58].

Various CLA isomers (cis9,trans 11 and trans 10 ,cis 12 in particular) were infused in the duodenum of dairy cows for three to five day periods. At low-dose $\left(1.25\right.$ to $\left.5 \mathrm{~g} \cdot \mathrm{d}^{-1}\right)$ trans 10 ,cis $12-18: 2$ greatly reduced lipid ( -7 to $36 \%)$ and short (C4:0 to $\mathrm{C} 8: 0)$ - or medium- (C10 to C16:0) chain FA secretions $[29,59,60]$. A decrease in long-chain (>C16) FA secretion was also noted during infusion of trans10,cis12-18:2, suggesting reduced uptake of circulating FAs. The C18:1/C18:0 ratio decreased in parallel, suggesting reduced delta- 9 desaturase activity [29, 61].

Those new results revived the theory of fatty acid biohydrogenation as the central mechanism of milk fat depression with certain diets [56, 62]. However, in some trials, ration supplementation with fish oil greatly reduced milk fat yield without any noticeable increase in trans 10,cis12-18:2 while increased rumenic acid accounted for $96 \%$ of the sharp increase in CLA $[63,64]$. Likewise, a low-fiber ration supplemented with linseed oil greatly reduced mammary lipid secretion without increasing trans10,cis12$18: 2$, neither in the duodenum [17] nor in milk [14]. Trans10,cis12-CLA therefore is not the only factor susceptible to induce milk fat depression. Other C18:1, C18:2 or C18:3 isomers produced in the rumen and/or in the udder might be involved ([14, 56, 57] and Loor et al., unpublished results). So, many questions are still to be unravelled, regarding the respective effects of these various isomers on the successive steps of mammary lipid synthesis. The transfer rate from duodenum to milk of long-chain FAs of dietary (PUFAs) or ruminal (trans-FAs) origin was lower with high-concentrate diets [18], suggesting that steps other than de novo FA synthesis and FA desaturation are altered with such diets.

Some of the decrease in lipid secretion under high-concentrate diets could also result from a propionate or glucose effect. However, duodenal infusion of $1.2 \mathrm{~kg} \cdot \mathrm{d}^{-1}$ glucose or its propionate equivalent only reduced lipid secretion by 5 to $8 \%$. Propionate altered the FA profile only slightly whereas glucose reduced short-chain FA (C4 to C8) and, more markedly, C18-FA secretion [65]. As the 2 infusion treatments decreased to the same extent the plasma acetate and $\beta-\mathrm{OH}$-butyrate concentrations [65], these changes cannot totally explain the different responses in milk FA profile.

If the milk fat depression could be related to the concentrations of certain trans FA in cows, the situation is less clear in goats. In that species, milk fat content and yield are not reduced, but are almost always increased by vegetable oil supplementation [7], even with low-fiber (Tabs. III and V) or maize silage-based (Tab. IV) diets. Milk fat content positive response to lipid supplementation was however lower when goats were given maize silage, reflecting either the high milk fat content ensured by this basal diet, or a negative effect of the trans 10-18:1 increase which was specifically induced by the maize silage-oil interaction, thus limiting the positive effect of oils on milk fat content and on CLA secretion which was otherwise observed with the alfalfa diet (Tab. IV). This was confirmed by the analysis of results from 19 diets studied on 181 goats, with combinations of 5 different forages without or with supplementation by 3 different oils (Fig. 5A). In the range of the 

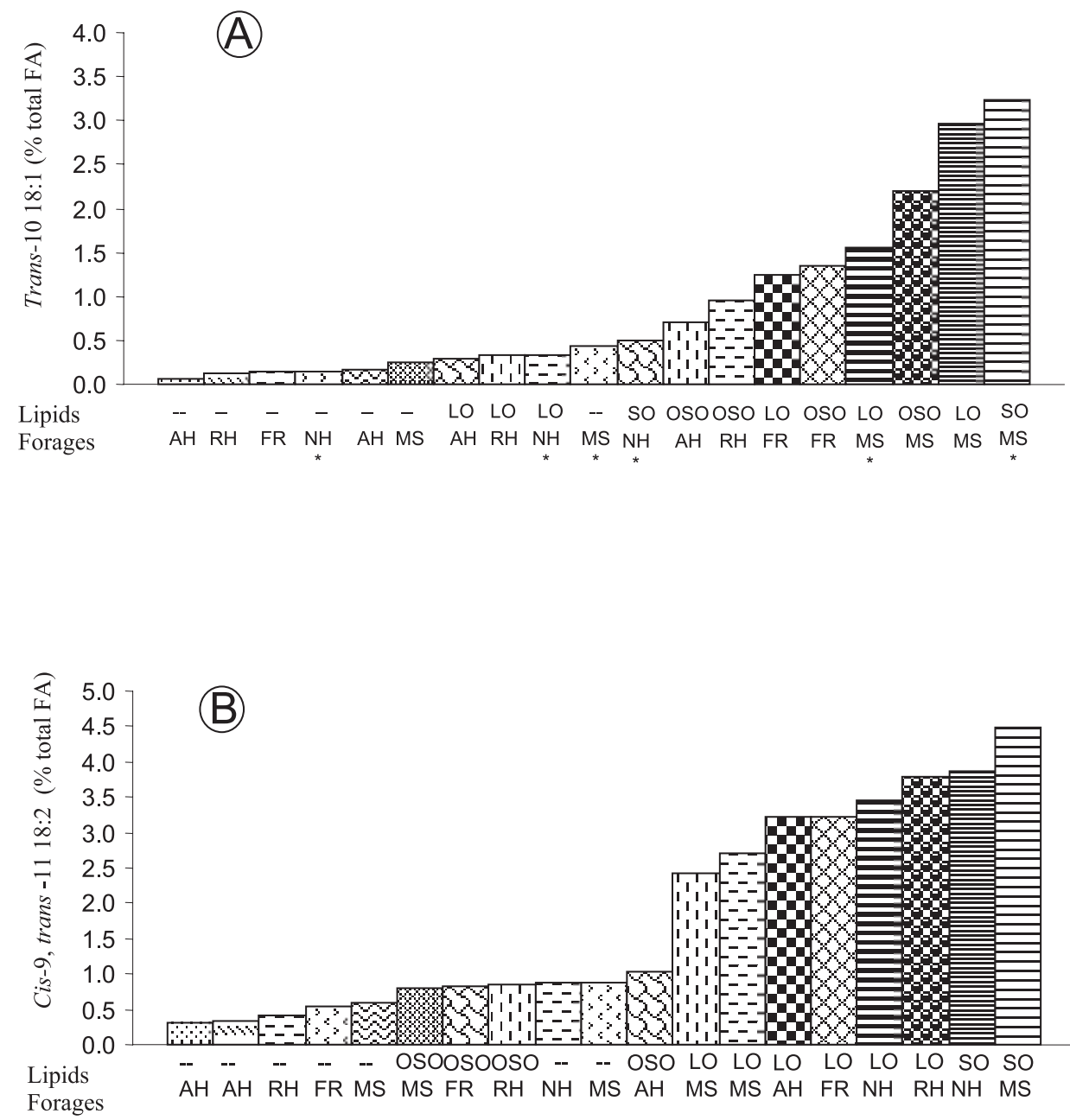

Figure 5. Forage-oil interactions on milk fat percentages of trans10-18:1 (A) and cis9, trans1118:2 (B), in goats receiving medium-concentrate (45-60\% of diet DM) diets supplemented, or not, with oil (5-6\% of diet DM) during 3(*)-5 weeks (10-14 goats per group; 181 goats) (adapted from $[7,15,81,82,83,108])$. Forages: AH, alfalfa hay; FR, fresh green rye-grass; $\mathrm{NH}$, natural grassland hay; MS, maize silage; RH, rye-grass hay. Lipids: --, control diet (without oil addition); LO, linseed oil; OSO, high-oleic sunflower oil; SO, sunflower oil.

concentrate percentages ( 45 to $60 \%$ ) of the diets that were studied, high concentrations of trans $10-18: 1$ (1.2 to $3.2 \%)$ were always observed with either maize silage or fresh green rye-grass diets supplemented with oleic-, linoleic- or linolenic-rich oil. For haybased diets, the highest values were observed with high-oleic sunflower oil supplementation, consistently with a possible cis9-18:1 isomerisation into trans 10-18:1 in the rumen [66].

In a goat trial using either green ryegrass or rye-grass or alfalfa hay as forage, and linseed oil or high oleic sunflower oil 
supplements to induce large variations in trans isomers [67], there was no correlation between the milk fat content and the proportions of the various trans-18:1 or CLA isomers (including trans10-isomers), contrary to what was observed in dairy cows (see above). However, goat milk fat content was negatively correlated with several saturated and mono-unsaturated $\mathrm{C} 14$ to $\mathrm{C} 16$ FAs and n-6 PUFAs, and positively with stearic acid [67], which confirmed that this substrate is a major regulating factor of mammary lipid secretion in that species, as suggested in earlier studies with lipid-poor diets [68]. Contrary to what was observed in the cow [58], vitamin E supplementation to goats receiving linseed oil did not interact with forage: concentrate ratio, and did not change either milk fat content or trans 10 18:1 percentage, although it increased the other trans-FAs and the 18:0, and decreased the C10-C16:0 percentages and the 18:0 desaturation ratio (Tab. V). Thus vitamin $\mathrm{E}$ tended to increase further the main effects of linseed oil addition to goat diet.

\subsubsection{Dietary variation factors}

The dietary factors that influence the milk CLA and trans 11-18:1 composition are included in two main categories: (1) diets providing lipid precursors (C18:2 or C18:3) for CLA and/or trans-18:1 formation in the rumen, (2) diets that modify the microbial activity associated with PUFA hydrogenation in the rumen. Combinations of these various factors induce wide variations of milk CLA and trans-18:1 concentrations (up to $4 \%$ rumenic acid and $10 \%$ vaccenic acid, Fig. 1), and strong interactions occur between forages, starchy concentrates and lipid supplements ([52], Figs. 2 and 5B, and Tabs. IV and V).

The proportions of trans-18:1 and CLA in cow's milk produced from maize silagebased diets (more than $60 \%$ of the ration) are small (1.1 to $2.2 \%$ and 0.4 to $0.6 \%$, respectively) ([20] and Fig. 2). CLA concentration in the milk of dairy cows switching from winter diet to young, natural meadow grass increases sharply [26, 69]. Nevertheless, the milk CLA proportions measured in cows at pasture are variable (0.5 to $1.7 \%$ ) (Tab. VI). Milk CLA concentration increases with green grass availability $[38,70]$ and is further increased by lipid supplements (Tab. VI and [71]). In other respects, the observed concentrations are higher in the Spring and in the Autumn than

Table VI. Effects of pasture with or without lipid supplements on milk fat CLA in dairy cows (review by Chilliard et al. [101]).

\begin{tabular}{lcccc}
\hline & \multicolumn{2}{c}{ Milk fat CLA (\% of total FA) } & Treatment duration & References \\
\cline { 1 - 3 } Winter diet & Pasture & Pasture + Lipid supplement & & \\
\hline 0.3 & 1.3 & - & - & {$[102]$} \\
0.3 & 0.6 & - & $4 \mathrm{mo}$ & {$[103]$} \\
0.4 & 1.2 & - & $3 \mathrm{wk}$ & {$[104]$} \\
0.5 & 1.1 & - & $4 \mathrm{wk}$ & {$[41]$} \\
0.4 & 0.7 & - & $4 \mathrm{mo}$ & {$[105]$} \\
0.4 & $1.1 / 1.4$ & - & $3 \mathrm{mo}$ & {$[106]$} \\
- & 0.5 & $0.5 / 0.8$ & $8 \mathrm{wk}$ & {$[70]$} \\
- & 1.7 & $1.5 / 2.2$ & $3 \mathrm{wk}$ & {$[39]$} \\
- & 0.8 & 1.3 & $6 \mathrm{wk}$ & {$[107]$} \\
0.3 & - & - & $4 \mathrm{wk}$ & {$[5]$} \\
0.6 & 1.7 & - & $3 \mathrm{wk}$ & {$[26]$} \\
0.6 & 0.8 & & $6 \mathrm{wk}$ & {$[26]$} \\
\hline
\end{tabular}



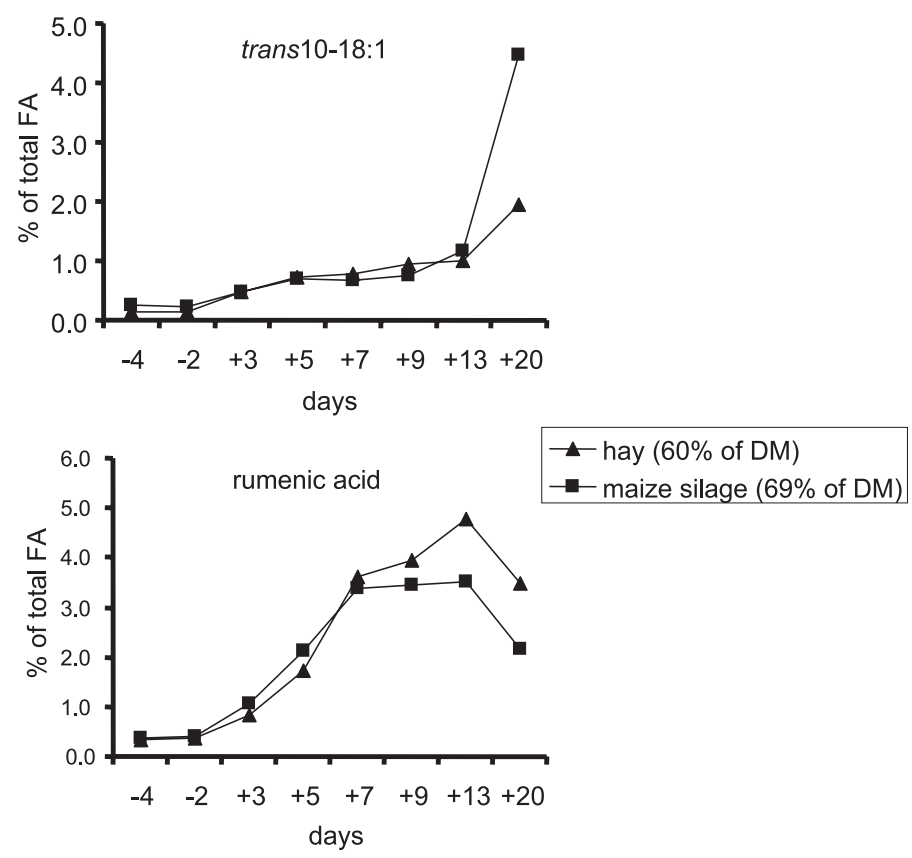

Figure 6. Effect of nature of forage on the kinetics of percentages of cow milk trans10-18:1 and rumenic acid after the addition of oil into the diet (adapted from [80]).

in Summer. Young grass high C18:3 concentration and low fiber content probably combine to increase CLA and trans-18:1 production. Also, the particular botanical composition of natural highland meadows seems to promote high milk CLA concentrations (up to $2.4 \%$, [72]), whereas a botanical composition effect of cultivated swards appears to be low [73]. Comparisons in cows (Figs. 2 and 6) suggest that the milk rumenic acid response to lipid supplementation differs between forages, with hay $>$ maize silage $>$ grass silage. Further studies are needed to confirm and explain these interactions.

C18:2-rich vegetable oils (sunflower, soybean) highly increase milk rumenic acid content. This effect is linear as increasing amounts of soybean oil are added to the diet (up to at least $4 \%$ of diet DM) ([9] and Fig. 2). Adding rapeseed oil calcium salts to the ration increased also milk rumenic acid concentration. This confirmed that calcium salts of PUFAs are partially hydrogenated. Overall, vegetable oils increase milk rumenic acid more than extruded seeds, which in turn increase it more than raw seeds ([74], Tabs. III and $\mathrm{V}$ ). This effect is therefore more or less marked as PUFAs from free oil, extruded seeds or raw seeds disrupt rumen metabolism more or less intensively, consistently with the respective effects of oils or seeds on milk trans 11-18:1 plus cis9,trans11-18:2 (Tabs. II-V and [31, 75]).

Increasing linseed oil (C18:3-rich) intake increased linearly milk rumenic acid concentration, almost as much as sunflower oil (C18:2-rich) when a grass silage based diet was used, and a little bit less when added to a maize silage diet (Fig. 2). That could be explained by a sharp increase in rumen transformation of C18:3 to trans11-18:1, which would be later taken up by the udder and desaturated by delta- 9 desaturase to yield 
rumenic acid. Surprisingly, addition of a very small level of linseeds $\left(21 \mathrm{~g} \cdot \mathrm{d}^{-1}\right.$, i.e. $8 \mathrm{~g}$ oil $)$ and $21 \mathrm{~g} \cdot \mathrm{d}^{-1}$ of trace element mixture increased significantly cows' milk rumenic and linolenic acids [76], and it remains to see if the effect what due either to linseeds or to trace elements.

Fish oils are more effective than vegetable oils, when equally added to the ration, at increasing the CLA concentration. So, CLA proportions increased from $0.2-0.6 \%$ with the control diet to $1.5-2.7 \%$ with diets supplemented with fish oil (200-300 $\mathrm{g} \cdot \mathrm{d}^{-1}$, $[20,24])$. It is likely that the PUFAs (EPA and DHA) of those oils increase trans 1118:1 concentration in the rumen, probably through inhibiting the reduction of that FA into stearic acid. That would explain why the combination of vegetable oils and fish oil strongly increased milk CLA content [77, 78].

Rumenic acid secretion in milk is correlated to the duodenal flow of trans11-18:1 [18]. Furthermore, there is a strong linear correlation between milk rumenic acid and trans 11-18:1 concentrations under a wide variety of diets, either in goats (Fig. 1) or cows. However, the milk rumenic acid/ trans 11-18:1 ratio could be decreased with fish oil supplementation [24]. In this case, the very high concentration of trans 11-18:1 may exceed the desaturation capacity of the mammary gland, or fish-oil specific FAs (EPA, DHA or intermediate hydrogenation compounds) may inhibit delta-9 desaturase activity.

Previous data [79] suggested that the milk rumenic acid response to lipid supplementation could be transient, with a maximum during the second week after the beginning of lipid supplementation. We confirmed this recently [80] and observed that the rumenic acid response to lipid supplementation was higher with hay diet than maize silage diet, and that the decrease after 3 weeks of supplementation was accompanied by an increase in milk fat trans 10-18:1 percentage, that was more marked with maize silage (Fig. 6). This confirms the the- ory proposed by Bauman and Griinari [56] and Bauman et al [57] on the trans10-18:1 pathway which would decrease the yield of ruminal vaccenic acid and its availability for rumenic acid synthesis in the mammary gland. This rises also the question of the sustainability of high CLA responses in dairy cattle, and further studies are needed on interactions between dietary fiber, starch, fatty acids and other components.

No data are available on the short-term kinetics of CLA response in goat milk. However the high CLA levels obtained after 5 weeks of lipid supplementation (Fig. 5B and Tabs. IV and V) have been confirmed in the same goats after 9-10 weeks of supplementation [81]. This shows that goat species is a very good responder and that its milk rumenic acid response is stable during at least 2-3 months. Indeed, goat milk rumenic acid varies largely according to feeding factors. The 19 diets studied in Figure 5B, with combinations of 5 different forages with either no oil addition or 18:1-, 18:2- or 18:3rich oils, yielded a range of rumenic acid from 0.3 to $4.5 \%$ of total FAs. The main factor of variation was the nature of oil with sunflower (18:2-rich) $\geq$ linseed (18:3-rich) $>>$ oleic sunflower (18:1-rich) > no oil addition. The response to oleic acid-rich oil, albeit much less than similar amount of either linseed or sunflower oil, is consistent with a possible cis9-18:1 isomerisation into trans 11-18:1 in the rumen [66] or could be to due an inhibition of the last step of hydrogenation of dietary PUFA. For a given oil supplementation, the response to oil interacted strongly with the nature of forage. Thus the response to sunflower oil was highest with maize silage, whereas the response to linseed oil was lower with maize silage than with either hays or fresh grass (Tab. IV and Fig. 5B). However, milk rumenic acid response to linseed oil supplementation was not changed when diet concentrate (or starch) percentage increased from $30 \%$ (or $8 \%$ ) to $54 \%$ (or 29\%, respectively) (Tab. V), and this was not changed by vitamin $\mathrm{E}$ supplementation. 
Few data are available on the influence of feeding on the various milk CLA isomers. Rumenic acid (cis9,trans 11-CLA) is classically the one whose concentration is the most variable because of the importance of its mammary synthesis by delta- 9 desaturase. In addition, this enzyme synthesizes trans 7, cis9-CLA, quantitatively the second isomer present in milk. That isomer is increased in cow by low-fiber diets supplemented with soybean oil [55] and probably in goats by high-oleic sunflower oil supplementation [82]. Low-fiber diets increase cis 11,trans13- and cis9, cis11-CLA isomers, whereas linseed oil increases cis9,cis11-, trans11,cis13- and trans11,trans13-CLA, as well as trans13-18:1, cis9,trans13-18:2 and trans 11 ,cis 15-18:2 ([14, 15] and Tab. V). It should be stressed that the obtention of a high level of rumenic acid (3-4\% of total FAs) is accompanied by high levels not only of vaccenic acid (8-10\%) but also of other trans-isomers of $\mathrm{C} 18: 1$ and conjugated or non-conjugated C18:2 (5-10\%) and C18:3 (Tab. V, and [14, 81, 83]). The respective physiological roles of these various isomers and their possible nutritional interest to man have not been studied to date.

\section{EFFECTS OF FEEDING FACTORS ON THE SENSORY QUALITY OF DAIRY PRODUCTS}

Before recommending dietary modifications to breeders to modify milk FA composition, it has to be ascertained that such practices would not be detrimental to the sensory quality of dairy products. Cow milk sensory analysis was performed by two comparisons (triangular tasting tests) of crude, unskimmed milk from groups of cows receiving different diets [84]. Differences exist between milk produced by grazing cows and others obtained from cows fed hay-based or high-concentrate diets. Also, milk samples from cows fed grass silage were identified as different from milk derived from hay-based or maize silage diets. Sup- plementing maize silage-based diets with $3 \%$ sunflower oil led to moderate but noticeable sensory differences, whereas the distinction is no longer possible with grass silage-based diets. Addition of 5\% linseed oil to a maize silage-based diet was easily identified. Adding $2.5 \%$ fish oil induced sensory defects.

Cheese or butter sensory qualities are defined by their aspect and texture, in addition to their organoleptic properties (flavour). Certain FAs exert a specific effect on the hardness and spreadability of butter. Increased palmitic acid concentration combined with a decrease in short-chain FAs lead to lower spreadability. The 16:0/ cis9$18: 1$ ratio is the most accurate indicator of butter firmess [85]. So, pasture grazing led to more spreadable butter with a reduced 16:0/cis9-18:1 ratio [86]. Also, butter derived from hay-based diets was rated as less firm and with less flavour than butter produced from a maize silage-based diet, in paralled with an increase in mono- and poly-unsaturated FAs with the hay-based diet [87].

With regard to cheese, the type of pasture induces a modification of milk fatty acid composition, which affects cheese texture. Unsaturated fatty acid-rich milk produces less firm Abondance cheeses [85]. Cantaltype cheeses produced with milk derived from high-concentrate diets are firmer than those obtained from natural grass, probably because of their higher C18:0 and lower PUFA concentations. Pasture led to more "animal" and less "bitter" and less "sour" odour, such differences being less marked with pasteurized milk [88]. Hay, compared with maize silage, led to Emmental cheeses containing more mono- and poly-unsaturated FAs but less firm and piquant in taste, with a less pronounced "bone-fruit" flavour [87].

Other experiments have also shown the effects of forage and lipid supplements and their interactions on goat cheese flavour $[89,90]$. Linseed oil or sunflower oil supplementation (5-6\% of the ration) reduces the "goaty" taste in milk or fresh cheese, linked to the lower secretion of lipase and 
reduced post-milking lipolysis [7]. Also, more bitter, piquant, oxidized or fishy flavours may occur, especially with the hay + linseed oil combination which maximizes milk C18:3 concentration (Tab. IV).

\section{CONCLUSION}

Feeding factors make it possible to vary milk FA composition in many ways. Recent advances in the knowledge of FA synthesis mechanisms [digestion and metabolism] and their putative physiological effects in human consumers have significantly boosted ongoing research and potential applications. As regards ruminant nutrition, the aim is to better understand the effects of using grass-based diets, new combinations of feedstuffs in concentrates, and oil seed technology and processing. However, very few direct comparisons have been made between the main types of basal diets (different types of forages, starchy concentrates, etc.) combined with various lipid supplements (oils, seeds, technological processing and lipid dose added to the basal diet). So, the trends reported in this paper need to be confirmed and specified. However, it is clear that the plasticity of milk fat composition is very large, according to numerous interactions between forage-concentratesoils-minerals-vitamins, time after dietary changes, as well as ruminant species [7, 109], on almost all major and minor FAs, including several trans isomers of C18:1, C18:2 and C18:3.

Insofar as human nutritional recommendations may still vary in the coming years, and as the putative effect of a large number of specific FAs (e.g. trans isomers of C18:1, C18:2, C18:3) on human health are not yet known, animal nutritionists have to keep exploring the response patterns of major and minor milk fatty acids and to model their synthesis mechanisms. At the same time, the side effects of the various dietary practices on health safety (presence of antinutritional factors, variations of nutrients with pro-oxidant effects, etc.), on technological and sensory quality as well as on the image of dairy products need to be better assessed.

\section{ACKNOWLEDGMENTS}

The authors thank J. Rouel, L. Bernard, P. Capitan, E. Bruneteau and A. Ollier for their participation to recent goat and/or cow experiments, and P. Béraud for assistance during the preparation of the manuscript. A part of the presented results were funded by the French Ministry of Research ("Aliment Qualité Sécurité" programme 2000/F16-00P0204) and the European Union (BIOCLA Project QLK1-2002-02362, and LIPGENE Contract FOOD-CT-2003-505944).

\section{REFERENCES}

[1] Williams CM. Dietary fatty acids and human health. Ann Zootech 2000, 49: 165-180.

[2] Gibson JP. The potential for genetic change in milk fat composition. J Dairy Sci 1991, 74: 3258-3266.

[3] Palmquist DL, Beaulieu AD, Barbano DM. Feed and animal factors influencing milk fat composition. J Dairy Sci 1993, 76: 17531771 .

[4] Lawless F, Stanton C, L'Escop P, Devery R, Dillon P, Murphy JJ. Influence of breed on bovine milk cis-9, trans-11-conjugated linoleic acid content. Livest Prod Sci 1999, 62: 43-49.

[5] Agenäs S, Holtenius K, Griinari M, Burstedt E. Effects of turnout to pasture and dietary fat supplementation on milk fat composition and conjugated linoleic acid in dairy cows. Acta Agric Scand, Sect A, Anim Sci 2002, 52: 25-33.

[6] Delaby L, Rulquin H, Peyraud JL. Influence de quelques facteurs zootechniques sur la composition en acides gras du lait de vaches au pâturage. Rencontres Recherches Ruminants 2002, 9: 364.

[7] Chilliard Y, Ferlay A, Rouel J, Lamberet G. A review of nutritional and physiological factors affecting goat milk lipid synthesis and lipolysis. J Dairy Sci 2003, 86: 1751-1770.

[8] Ferlay A, Verdier-Metz I, Pradel P, Martin B, Van der Horst H, Ballot N, Chilliard Y. Effets respectifs d'une alimentation à base d'herbe et de la transformation fromagère sur la composition en acides gras d'intérêt nutritionnel de fromage de type Saint-Nectaire ou Cantal. Rencontres Recherches Ruminants 2002, 9: 367. 
[9] Chilliard Y, Ferlay A, Mansbridge RM, Doreau M. Ruminant milk fat plasticity: nutritional control of saturated, polyunsaturated, trans and conjugated fatty acids. Ann Zootech 2000, 49: 181-205.

[10] Glass RL, Troolin HA, Jenness R. Comparative biochemical studies of milks. IV. Constituent fatty acids of milk fats. Comp Biochem Physiol 1967, 22: 415-425.

[11] Bickerstaffe R, Annison EF, Linzell J. The metabolism of glucose, acetate, lipids and amino acids in lactating dairy cows. J Agric Sci Camb 1974, 82: 71-85.

[12] EnjalbertF, Nicot MC, Bayourthe C, Moncoulon R. Duodenal infusions of palmitic, stearic or oleic acids differently affect mammary gland metabolism of fatty acids in lactating dairy cows. J Nutr 1998, 128: 1525-1532.

[13] Griinari JM, Bauman DE. Biosynthesis of conjugated linoleic acid and its incorporation into meat and milk in ruminants. In: Yurawecz MP, Mossoba MM, Kramer JKG, Pariza MW, Nelson GL (Eds), Advances in Conjugated Linoleic Acid Research, Vol 1, Am Oil Chem Soc Press, Champaign, Illinois, 1999, p 180 200.

[14] Loor JJ, Ferlay A, Ollier A, Doreau M, Chilliard Y. Conjugated linoleic acids (CLA), trans fatty acids, and lipid content in milk from Holstein cows fed a high or low fiber diet with two levels of linseed oil. ADSA-ASAS-CSAS Annual Meeting, Quebec City, Canada, 22-24 July. J Dairy Sci 2002, 85 (Suppl 1): 297.

[15] Chilliard Y, Rouel J, Chabosseau JM, Capitan P, Gaborit P, Ferlay A. Interactions between raygras preservation and linseed oil supplementation on goat milk yield and composition, including trans and conjugated fatty acids. In: van der Honing Y (Ed), Wageningen Acad Publ (NL) Book of Abstracts of the 54th Annual Meeting of European Association for Animal Production, Rome, Italy, 31 August3 September 2003, p 343.

[16] Keeney M. Lipid metabolism in the rumen. In: Phillipson AT (Ed), Physiology of digestion and metabolism in the ruminant, Oriel Press, Newcastle Upon Tyne, 1970, p 489-503.

[17] Loor JJ, Ueda K, Ferlay A, Chilliard Y, Doreau M. Biohydrogenation, duodenal flow, and intestinal digestibility of trans fatty acids and conjugated linoleic acids in response to dietary forage: concentrate ratio and linseed oil in dairy cows. J Dairy Sci 2004, 87: 2472-2485.

[18] Loor JJ, Ueda K, Ferlay A, Doreau M, Chilliard Y. Transfer of dietary fatty acids and hydrogenation intermediates from duodenum to milk in cows fed diets varying in forage: concentrate ratio and level of linseed, sunflower or fish oil. Proc ASAS-ADSA Meeting, Phoe- nix, USA, 22-26 June, J Dairy Sci 2003, 86 (Suppl 1): 272.

[19] Doreau M, Ferlay A. Digestion and utilisation of fatty acids by ruminants, Anim Feed Sci Technol 1994, 45: 379-396.

[20] Chilliard Y, Ferlay A, Doreau M. Effect of different types of forages, animal fat or marine oils in cow's diet on milk fat secretion and composition, especially conjugated linoleic acid (CLA) and polyunsaturated fatty acids. Livest Prod Sci 2001, 70: 31-48.

[21] Bauman DE, Davis CL. Biosynthesis of milk fat. In: Larson BL, Smith VR (Eds), Lactation, a comprehensive treatise, Vol II, Academic Press, New York, 1974, 31-75.

[22] Palmquist DL, Jenkins TC. Fat in lactation rations for dairy: a review. J Dairy Sci 1980, 63: 1-14.

[23] Parodi PW. Conjugated linoleic acid and other anticarcinogenic agents of bovine milk fat. J Dairy Sci 1999, 82: 1339-1349.

[24] Chilliard Y, Ferlay A, Doreau M. Contrôle de la qualité nutritionnelle des matières grasses du lait par l'alimentation des vaches laitières : acides gras trans, polyinsaturés, acide linoléique conjugué. INRA Productions Animales 2001, 14: 323-335.

[25] Jenkins TC. Fatty acid composition of milk from Holstein cows fed oleamide or canola oil. J Dairy Sci 1998, 81: 794-800.

[26] Ferlay A, Martin B, Pradel Ph, Capitan P, Coulon JB, Chilliard Y. Effects of the nature of forages on cow milk fatty acids having a positive role on human health. In: Durand JL, Emile JC, Huyghe C, Lemaire G (Eds), Proc 19 th General Meeting of the European Grassland Federation. La Rochelle, France, 27-30 May 2002. Multi-function grasslands: quality forages, animal products and landscapes. Grassland Science in Europe, 2002, Vol 7, Br Grassland Soc, Reading, UK, p 556-557.

[27] Sessler AM, Ntambi JM. Polyunsaturated fatty acid regulation of gene expression. J Nutr 1998, 128: 923-926.

[28] Baumgard LH, Corl BA, Dwyer DA, Saebo A, Bauman DE. Identification of the conjugated linoleic acid isomer that inhibits milk fat synthesis. Am J Physiol Regul Integr Comp Physiol 2000, 278: R179-R184.

[29] Baumgard LH, Sangster JK, Bauman DE. Milk fat synthesis in dairy cows is progressively reduced by increasing supplemental amounts of trans-10, cis-12 conjugated linoleic acid (CLA). J Nutr 2001, 131: 1764-1769.

[30] Jouany JP, Michalet-Doreau B, Doreau M. Manipulation of the rumen ecosystem to support high-performance beef cattle. AsianAustralas J Anim Sci 2000, 13: 96-114. 
[31] Chouinard PY, Levesque J, Girard V, Brisson GJ. Dietary soybeans extruded at different temperatures: milk composition and in situ fatty acid reactions. J Dairy Sci 1997 80: 2913-2924.

[32] McDonald IW, Scott TW. Foods of ruminant origin with elevated content of polyunsaturated fatty acids. World Rev Nutr Diet 1977 , 26: 144-207.

[33] Ferlay A, Chilliard Y, Doreau M. Effects of calcium salts differing in fatty acid composition on duodenal and milk fatty acid profiles in dairy cows. J Sci Food Agric 1992, 60: 31-37.

[34] Ferlay A, Chabrot J, Elmeddah Y, Doreau M. Ruminal lipid balance and intestinal digestion by dairy cows fed calcium salts of rapeseed oil fatty acids or rapeseed oil. J Anim Sci 1993 , 71: 2237-2245.

[35] Boufaïed H, Chouinard PY, Tremblay GF, Petit HV, Michaud R, Bélanger G. Fatty acids in forages. I. Factors affecting concentrations. Can J Anim 2003, 83: 501-511.

[36] Bauchart D, Vérité R, Rémond B. Long-chain fatty acid digestion in lactating cows fed fresh grass from spring to autumn. Can J Anim Sci 1984, 64 Suppl: 330-331.

[37] Decaen C, Ghadaki MB. Variation de la sécrétion des acides gras des matières grasses du lait de vache à la mise à l'herbe et au cours des six premières semaines d'exploitation du fourrage vert. Ann Zootech 1970, 19: 399411.

[38] Dhiman TR, Anand GR, Satter LD, Pariza MW. Conjugated linoleic acid content of milk from cows fed different diets. J Dairy Sci 1999, 82: 2146-2156.

[39] Lawless F, Murphy JJ, Harrington D, Devery $\mathrm{R}$, Stanton C. Elevation of conjugated cis-9, trans-11-Octadecadienoic acid in bovine milk because of dietary supplementation. J Dairy Sci 1998, 81: 3259-3267.

[40] Kennelly JJ. The fatty acid composition of milk fat as influenced by feeding oilseeds. Anim Feed Sci Tech 1996, 60: 137-152.

[41] Kelly ML, Berry JR, Dwyer DA, Griinari JM, Chouinard PY, Van Amburgh ME, Bauman DE. Dietary fatty acid sources affect conjugated linoleic acid concentrations in milk from lactating dairy cows. J Nutr 1998, 12: 8881-885.

[42] Brunschwig P, Morel d'Arleux F, Colin G, Evrard J. Effets de l'apport de tourteau de lin sur les performances de vaches laitières à l'ensilage de maïs. Rencontres Recherches Ruminants 1996, 3: 285-288.
[43] Brunschwig P, Kernen P, Weill P. Effets de l'apport d'un concentré enrichi en acides gras polyinsaturés sur les performances de vaches laitières à l'ensilage de maïs. Rencontres Recherches Ruminants 1997, 4: 361.

[44] Offer NW, Marsden M, Phipps RH. Effect of oil supplementation of a diet containing a high concentration of starch on levels of trans fatty acids and conjugated linoleic acids in bovine milk. Anim Sci 2001, 73: 533-540.

[45] Focant M, Mignolet E, Marique M, Clabots F, Breyne T, Dalemans D, Larondelle Y. The effect of vitamin E supplementation of cow diets containing rapeseed and linseed on the prevention of milk fat oxidation. J Dairy Sci 1998, 81: 1095-1101.

[46] Weill P, Schmitt B, Chesneau G, Daniel N, Safraou F, Legrand P. Effects of introducing linseed in livestock diet on blood fatty acid composition of consumers of animal products. Ann Nutr Metab 2002, 46: 182-191.

[47] Giger-Reverdin S, Weill P, Duvaux-Ponter C, Morand-Fehr P, Rouzeau A, Sauvant D. Influence du degré d'insaturation des matières grasses alimentaires (lin vs. colza) sur la composition en acides gras de la matière grasse du lait de chèvre en début de lactation. Rencontres Recherches Ruminants 2001, 8: 101.

[48] Goodridge J, Ingalls JR.Transfer or omega-3 linolenic acid from flaxseed to milk fat. J Anim Sci 1998, 76 (Suppl 1): 353.

[49] Petit HV. Digestion, milk production, milk composition, and blood composition of dairy cows fed formaldehyde treated flaxseed or sunflower seed. J Dairy Sci 2003, 86: 2637 2646.

[50] Ueda K, Ferlay A, Chabrot J, Loor J, Chilliard Y, Doreau M. Effect of linseed oil supplementation on ruminal digestion in dairy cows fed diets with different forage:concentrate ratios. J Dairy Sci 2003, 86: 3999-4007.

[51] Davis CL, Brown RE. Low-fat milk syndrome. In: Phillipson AT (Ed), Physiology of Digestion and Metabolism in the Ruminant, Orial Press, Newcastle, UK, 1970, p 545-565.

[52] Griinari JM, Dwyer DA, McGuire MA, Bauman DE, Palmquist DL, Nurmela KVV. Transoctadecenoic acids and milk fat depression in lactating dairy cows. J Dairy Sci 1998, 81: 1251-1261.

[53] Morales MS, Palmquist DL, Weiss WP. Milk fat composition of Holstein and Jersey cows with control or depleted copper status and fed whole soybeans or tallow. J Dairy Sci 2000, 83: 2112-2119. 
[54] Banks W, Clapperton JL, Kelly ME, Wilson AG, Crawford RJM. The yield, fatty acid composition and physical properties of milk fat obtained by feeding soya oil to dairy cows. J Sci Food Agric 1980, 368-374.

[55] Piperova LS, Teter BB, Bruckental I, Sampugna J, Mills SE, Yurawecz MP, Fritsche J, Ku K, Erdman RA. Mammary lipogenic enzyme activity, trans fatty acids and conjugated linoleic acids are altered in lactating dairy cows fed a milk fat-depressing diet. J Nutr 2000, 130: 2658-2674.

[56] Bauman DE, Griinari JM. Regulation and nutritional manipulation of milk fat: low-fat milk syndrome. Livest Prod Sci 2001, 70: 15-29.

[57] Bauman DE, Corl BA, Baumgard LH, Griinari JM. Conjugated linoleic acid (CLA) and the dairy cow. In: Garnsworthy PC, Wiseman J (Eds), Recent Advances in Animal Nutrition, Nottingham University Press, Nottingham, UK, 2001, p 221-250.

[58] Focant M, Griinari M, Mignolet E, Larondelle Y. Effet de la supplémentation en vitamine $\mathrm{E}$ sur la production d'acides linoléiques conjugués par la vache laitière. Symposium « Santé animale, santé humaine. Productions animales naturellement riches en oméga 3 et CLA favorables à la santé », Ciney, Belgique, 26 octobre 2001, 2 p.

[59] Loor JJ, Herbein JH. Exogenous conjugated linoleic acid isomers reduce bovine milk fat concentration and yield by inhibiting de novo fatty acid synthesis. J Nutr 1998, 128: 24112419.

[60] Loor JJ, Ferlay A, Doreau M,.Chilliard Y. Intestinal supply of trans10, cis12-18:2 lowers milk fat output in Holstein cows fed a highor low-fiber diet with two levels of linseed oil. ADSA-ASAS-CSAS Annual Meeting, Quebec City, Canada, 22-24 July. J Dairy Sci 2002, 85 (Suppl 1): 297.

[61] Chouinard PY, Corneau L, Saebo A, Bauman DE. Milk yield and composition during abomasal infusion of conjugated linoleic acids in dairy cows. J Dairy Sci 1999, 82: 2737-2745.

[62] Griinari JM, Bauman DE. Update on theories of diet-induced milk fat depression and potential applications. Rec Adv Anim Nutr 2003, 37: 115-156.

[63] Chilliard Y, Chardigny JM, Chabrot J, Ollier A, Sébédio JL, Doreau M. Effects of ruminal or postruminal fish oil supply on conjugated linoleic acid (CLA) content of cow milk fat. Proc Nutr Soc 1999, 58: 70A.

[64] Loor JJ, Chardigny JM, Chabrot J, Doreau M, Ollier A, Sebedio JL, Chilliard Y. Trans-fatty acids, CLA isomers, and milk fat depression in dairy cows receiving incremental doses of fish oil. Proc ASAS-ADSA Meeting, Phoenix, USA, 22-26 June. J Dairy Sci 2003, 86 (Suppl 1): 272.

[65] Rigout S, Hurtaud C, Lemosquet S, Bach A, Rulquin H. Lactational effect of propionic acid and duodenal glucose in cows. J. Dairy Sci 2003, 86: 243-253.

[66] Mosley EE, Powell GL, Riley MB, Jenkins TC. Microbial biohydrogenation of oleic acid to trans isomers in vitro. J Lipid Res 2002, 43: 290-296.

[67] Chilliard Y, Rouel J, Capitan P, Chabosseau JM, Raynal-Ljutovac K, Ferlay A. Correlations between milk fat content and fatty acid composition in goats receiving different combinations of forages and lipid supplements. In: van der Honing Y (Ed), Wageningen Acad Publ (NL) Book of Abstracts of the 54th Annual Meeting of European Association for Animal Production, Rome, Italy, 31 August3 September 2003, p 343.

[68] Delage J, Fehr PM. Influence des lipides alimentaires sur la sécrétion des acides gras par la mamelle de chèvre. I. Influence de la teneur du régime en lipides sur le taux butyreux du lait et sa composition en acides gras. Ann Biol Anim Biochim Biophys 1967, 7: 437-444.

[69] Kuzdzal-Savoie, S, Kuzdzal W. Influence de la mise à l'herbe des vaches laitières sur les indices de la matière grasse du beurre et sur les teneurs en différents acides gras polyinsaturés. Ann Biol Anim Biochim Biophys 1961, 1: 47-69.

[70] Stanton C, Lawless F, Kjellmer G, Harrington D, Devery R, Connolly JF, Murphy J. Dietary influences on bovine milk cis-9, trans-11conjugated linoleic acid content. J Food Sci 1997, 62: 1083-1086.

[71] Schroeder GF, Gagliostro GA, Bargo F, Delahoy JE, Muller LD. Effects of fat supplementation on milk production and composition by dairy cows on pasture: a review. Livest Prod Sci 2004, 86: 1-18.

[72] Collomb M, Bütikofer U, Sieber R, Bosset JO, Jeangros B. Conjugated linoleic acid and trans fatty acid composition of cows' milk fat produced in lowlands and highlands. J Dairy Res 2001, 68: 519-523.

[73] Delagarde R, Peyraud JL. Fatty acid composition of milk from dairy cows as affected by grazing different grass species or cultivars. In: Durand JL, Emile JC, Huyghe C, Lemaire G (Eds), Proc 19th General Meeting of the European Grassland Federation, La Rochelle, France, 27-30 May 2002, Multi-function grasslands: quality forages, animal products and landscapes. Grassland Science in Europe, Vol 7 , 
2002, Br Grassland Soc, Reading, UK, p 554 555.

[74] Chouinard PY, Corneau L, Butler WR, Chilliard Y, Drackley JK, Baumand DE. Effect of dietary lipid source on conjugated linoleic acid concentrations in milk fat. J Dairy Sci 2001 84: 680-690.

[75] Bayourthe C, Enjalbert F, Moncoulon R. Effects of different forms of canola oil fatty acids plus canola meal on milk composition and physical properties of butter. J Dairy Sci 2000, 83: 690-696.

[76] Reklewska B, Oprzadek A, Reklewski Z, Panicke L, Kuczynska B, Oprzadek J. Alternative for modifying the fatty acid composition and decreasing the cholesterol level in the milk of cows. Livest Prod Sci 2002, 76: 235243.

[77] Palmquist DL. Ruminal and endogenous synthesis of CLA in cows. Aust J Dairy Technol 2001, 56: 134-137.

[78] Whitlock LA, Schingoethe DJ, Hippen AR, Kalscheur KF, Baer RJ, Ramaswamy N, Kasperson KM. Fish oil and extruded soybeans fed in combination increase conjugated linoleic acids in milk of dairy cows more than when fed separately. J Dairy Sci 2002, 85: 234-243.

[79] Bauman DE, Barbano DM, Dwyer DA, Griinari JM. Technical Note: Production of butter with enhanced conjugated linoleic acid for use in biomedical studies with animal models. J Dairy Sci 2000, 83: 2422-2425.

[80] Ferlay A, Capitan P, Ollier A, Chilliard Y. Interactions between nature of forage and oil supplementation on cow milk composition. 3 . Effects on kinetics of percentages of milk CLA and trans fatty acids. In: van der Honing Y (Ed), Wageningen Acad Publ (NL), Book of Abstracts of the 54th Annual Meeting of European Association for Animal Production, Rome, Italy, 31 August-3 September 2003, p 120.

[81] Chilliard Y, Bernard L, Rouel J, Ferlay A, Gaborit P, Raynal-Ljutovac K, Lauret A. Effet de l'alimentation et de sa composition en matière grasse sur la qualité du lait et des produits laitiers caprins (aptitude technologique, qualité sensorielle) et la production d'acides gras présentant un avantage pour la santé du consommateur. Compte rendu de fin de recherche d'opération d'une recherche financée par le ministère de la recherche, INRA-ITPLC, 2004, p 1-39.

[82] Ferlay A, Rouel J, Chabosseau JM, Capitan P, Raynal-Ljutovac K, Chilliard Y. Interactions between raygrass preservation and high-oleic sunflower oil supplementation on goat milk composition, including trans and conjugated fatty acids. In: van der Honing Y (Ed), Wageningen Acad Publ (NL), Book of Abstracts of the 54th Annual Meeting of European Association for Animal Production, Rome, Italy, 31 August-3 September 2003, p 350.

[83] Chilliard Y, Rouel J, Ferlay A, Bernard L, Gaborit P, Raynal-Ljutovac K, Lauret A. Effects of type of forage and lipid supplementation on goat milk fatty acids and sensorial properties of cheeses, Zaragoza, Spain, International Dairy Federation Symposium, 28-30 October 2004, in press, 6 p.

[84] Dubroeucq H, Martin B, Ferlay A, Pradel P, Verdier-Metz I, Chilliard Y, Agabriel J, Coulon JB. L'alimentation des vaches peut modifier les caractéristiques sensorielles du lait. Rencontres Recherches Ruminants 2002, 9: 351354.

[85] Hurtaud C, Buchin S, Martin B, Verdier-Metz I, Peyraud JL, Noël Y. La qualité des laits et ses conséquences sur la qualité des produits de transformation: quelques techniques de mesure dans les essais zootechniques. Rencontres Recherches Ruminants 2001, 8: 35-42.

[86] Hurtaud C, Delaby L, Peyraud J.L. Evolution of milk composition and butter properties during the transition between winter-feeding and pasture. Grassland Science in Europe 2002, 7: 574-575.

[87] Hurtaud C, Goudebranche H, Delaby L, Camier-Caudron B, Peyraud JL. Effet de la nature du régime hivernal sur la qualité du beurre et de l'emmental. Rencontres Recherches Ruminants 2002, 9: 369.

[88] Verdier-Metz I, Martin B, Hulin S, Ferlay A, Pradel P, Coulon JB. Combined influence of cow diet and pasteurisation of the milk on sensory properties of French PDO Cantal cheese. Illustrated on CDrom, Congrilait 26, World Dairy Congress, Paris, September 24-27, 2002.

[89] Gaborit P, Raynal K, Lauret A, Chabosseau JM, Rouel J, Chilliard Y. Flavour of goat milk and cheeses according to feeding: alfalfa hay or maize silage with oleic sunflower or linseed oil supplementation. In: Durand JL, Emile JC, Huyghe C, Lemaire G (Eds), Proc 19th General Meeting of the European Grassland Federation, La Rochelle, France, 27-30 May 2002, Multi-function grasslands: quality forages, animal products and landscapes. Grassland Science in Europe, Vol 7, 2002, Br. Grassland Soc, Reading, UK, p 562-563.

[90] Gaborit P, Rouel J, Bruneteau E, RaynalLjutovac K, Ferlay A, Lauret A, Chilliard Y. Impact of dietary lipid supplementation on goat milk fat and sensorial properties of cheeses. In: Proc 8th Int Conference on Goats, Pretoria, South Africa, 4-9 July 2004, p. 41. 
[91] Ward AT, Wittenberg KM, Przybylski R. Bovine milk fatty acid profiles produced by feeding diets containing solin, flax and canola. J Dairy Sci 2002, 85: 1191-1196.

[92] Casper DP, Schingoethe DJ, Middaugh RP, Baer RJ. Lactational response of dairy cows to diets containing regular and high oleic acid sunflower seeds. J Dairy Sci 1988, 71: 12671274.

[93] Abel-Caines SF, Grant RJ, Morrison M. Effect of soybean hulls, soy lecithin, and soapstock mixtures on ruminal fermentation and milk composition in dairy cows. J Dairy Sci 1998 , 81: 462-470.

[94] Palmquist DL, Conrad HR. High fat rations for dairy cows. Effects on feed intake, milk and fat production, and plasma metabolites. J Dairy Sci 1978, 61: 890-901.

[95] AbuGhazaleh AA, Schingoethe DJ, Hippen AR, Kalscheur KF, Whitlock LA. Fatty acid profiles of milk and rumen digesta from cows fed fish oil, extruded soybeans or their blend. J Dairy Sci 2002 85: 2266-2276.

[96] Loor JJ, Herbein JH, Jenkins TC. Nutrient digestion, biohydrogenation, and fatty acid profiles in blood plasma and milk fat from lactating Holstein cows fed canola oil or canolamide. Anim Feed Sci Technol 2002, 97: 65-82.

[97] Dhiman TR, Satter LD, Pariza MW, Galli MP, Albright K, Tolosa MX. Conjugated linoleic acid (CLA) content of milk from cows offered diets rich in linoleic and linolenic acids. J Dairy Sci. 2000, 83: 10161027.

[98] Chilliard Y, Rouel J, Leloutre L, Bruneteau E, Capitan P, Lauret A, Ferlay A. Effects of extruded linseed substitution to linseed oil and/or soybean meal, on milk yield and fatty acid (FA) composition in goats receiving a high-forage diet. In: van der Honing Y (Ed), Wageningen Acad Publ (NL), Book of Abstracts of the 55th Annual Meeting of European Association for Animal Production, Bled, Slovenia, 5-9 September 2004, p. 135.

[99] Ferlay A, Rouel J, Capitan P, Bruneteau E, Gaborit P, Leloutre L, Chilliard Y. Concentrate level and vitamin $\mathrm{E}$ supplementation do not interact on milk yield and fatty acid (FA) composition in goats receiving alfalfa hay and linseed oil. In: van der Honing Y (Ed), Wageningen Acad Publ (NL), Book of Abstracts of the 55th Annual Meeting of European Association for Animal Production, Bled, Slovenia, 5-9 September 2004, p. 119.

[100] Rouel J, Ferlay A, Bruneteau E, Capitan P, Raynal-Ljutovac K, Chilliard Y. Interactions between starchy concentrate and linseed oil supplementation on goat milk yield and composition, including trans and conjugated fatty acids (FA). In: van der Honing Y (Ed), Wageningen Acad Publ (NL), Book of Abstracts of the 55th Annual Meeting of European Association for Animal Production, Bled, Slovenia, 5-9 September 2004, p. 124.

[101] Chilliard Y, Ferlay A, Loor J, Rouel J, Martin B. Trans and conjugated fatty acids in milk from cows and goats consuming pasture or receiving vegetable oils or seeds. Italian $\mathrm{J}$ Anim Sci 2002, 1: 243-254.

[102] Timmen H, Patton S. Milk fat globules: fatty acid composition, size and in vivo regulation of fat liquidity. Lipids 1988, 23: 685-689.

[103] Jahreis G, Fritsche J, Steinhart H. Conjugated linoleic acid in milk fat: high variation depending on production system. Nutr Res 1997, 9: 1479-1484.

[104] Precht D, Molkentin J. Effect of feeding on conjugated cis-9, trans-11 octadecadienoic acid and other isomers of linoleic acid in bovine milk fats. Nahrung 1997, 41: 330 335.

[105] White SL, Bertrand JA, Wade MR, Washburn SP, Green JT Jr, Jenkins TC. Comparison of fatty acid content of milk from Jersey and Holstein cows consuming pasture or a total mixed ration. J Dairy Sci 2001, 84: 22952301.

[106] Loor JJ, Herbein JH,. Polan CE. Trans 18:1 and 18:2 isomers in blood plasma and milk fat of grazing cows fed a grain supplement containing solvent-extracted or mechanically extracted soybean meal. J Dairy Sci 2002, 85: 1197-1207.

[107] Tesfa AT, Tuori M, Holma M, Syrjälä-Qvist L. Effects of dietary trans fatty acid on the yield of milk fat conjugated linoleic acid (CLA) from cows grazing pasture. In: EAAP - 52nd Annual Meeting, Budapest, 2001, p 116.

[108] Rouel J, Ferlay A, Chabosseau JM, Capitan P, Gaborit P, Chilliard Y. Effects of fresh raygrass, raygrass hay or alfalfa hay on goat milk yield and composition, including trans and conjugated fatty acids. In: van der Honing Y (Ed), Wageningen Acad Publ (NL), Book of Abstracts of the 54th Annual Meeting of European Association for Animal Production, Rome, Italy, 31 August-3 September 2003, p 349.

[109] Schmidely P, Sauvant D. Taux butyreux et composition de la matière grasse du lait chez les petits ruminants : effets de l'apport de matières grasses ou d'aliment concentré. INRA Prod Anim 2001, 14: 337-354. 